\title{
Review \\ Involvement of the Orexinergic System in Feeding
}

\author{
Pilar Marcos ${ }^{1, *(1)}$ and Rafael Coveñas 2,3 () \\ 1 CRIB (Regional Centre of Biomedical Research), Cellular Neuroanatomy and Molecular Chemistry of \\ Central Nervous System, Faculty of Medicine, University of Castilla-La Mancha, Avenida de Almansa 14, \\ 02006 Albacete, Spain \\ 2 Laboratory of Neuroanatomy of the Peptidergic Systems, Institute of Neurosciences of Castilla y \\ León (INCYL), University of Salamanca, c/Pintor Fernando Gallego 1, 37007 Salamanca, Spain; \\ covenas@usal.es \\ 3 Group GIR-BMD (Bases Moleculares del Desarrollo), University of Salamanca, 37007 Salamanca, Spain \\ * Correspondence: Pilar.Marcos@uclm.es
}

Citation: Marcos, P.; Coveñas, R. Involvement of the Orexinergic

System in Feeding. Appl. Sci. 2022, 12, 86. https://doi.org/10.3390/ app12010086

Academic Editors: Grazia Maugeri and Velia D'Agata

Received: 24 November 2021

Accepted: 20 December 2021

Published: 22 December 2021

Publisher's Note: MDPI stays neutral with regard to jurisdictional claims in published maps and institutional affiliations.

Copyright: (C) 2021 by the authors. Licensee MDPI, Basel, Switzerland. This article is an open access article distributed under the terms and conditions of the Creative Commons Attribution (CC BY) license (https:// creativecommons.org/licenses/by/ $4.0 /)$.

\begin{abstract}
To know the processes involved in feeding, the dysregulation of hypothalamic neuropeptides promoting anorexigenic/orexigenic mechanisms must be investigated. Many neuropeptides are involved in this behavior and in overweight/obesity. Current pharmacological strategies for the treatment of obesity are unfortunately not very effective and, hence, new therapeutic strategies must be investigated and developed. Due to the crucial role played by orexins in feeding behavior, the aim of this review is to update the involvement of the orexinergic system in this behavior. The studies performed in experimental animal models and humans and the relationships between the orexinergic system and other substances are mentioned and discussed. Promising research lines on the orexinergic system are highlighted (signaling pathways, heterogeneity of the hypothalamic orexinergic neurons, receptor-receptor interaction, and sex differences). Each of the orexin 1 and 2 receptors plays a unique role in energy metabolism, exerting a differential function in obesity. Additional preclinical/clinical studies must be carried out to demonstrate the beneficial effects mediated by orexin receptor antagonists. Because therapies applied are in general ineffective when they are directed against a single target, the best option for successful anti-obesity treatments is the development of combination therapies as well as the development of new and more specific orexin receptor antagonists.
\end{abstract}

Keywords: feeding; obesity; orexin A; orexin B; orexin receptor; orexinergic peptide; prepro-orexin

\section{Introduction}

The hypothalamus is a regulator center involved in the integration of multiple factors and in the regulation of numerous homeostatic functions. Among them, the control of energy balance is one of the most complex hypothalamic tasks, as it also requires the coordinated participation of other brain regions and substances secreted by peripheral organs, such as the gastrointestinal tract or the adrenal glands. These peripheric signals send information to the central nervous system about the state of the energy stores, affecting the energy intake and expenditure [1-3]. For example, it was reported that gastric distension has a satiating effect [3]. In the control of food intake, a short-term regulation determines the beginning and the end of a meal; a long-term regulation helps to regulate the energy depots, and satiety regulates the interval between meals [3]. The balance between food intake and energy expenditure determines long-term energy homeostasis [1].

The regulation of feeding behavior is a complex mechanism exerted mainly by neuropeptides and neurotransmitters at the hypothalamic level, and the activity of certain hypothalamic neuronal groups sets the balance for maintaining proper homeostasis. In this regard, the activity of neurons located in the arcuate nucleus is particularly important. A group of neurons in this nucleus contain neuropeptide Y (NPY) and agouti-related peptide (AgRP) and are orexigenic, i.e., they promote food intake. These neurons are 
inhibitory for another population of neurons located in the arcuate nucleus that contain proopiomelanocortin (POMC) and cocaine- and amphetamine-regulated transcript (CART), are anorexigenic, and inhibit feeding; see [4,5] for review. The interaction of both systems, POMC/CART and NPY/AgRP, is the basis for the regulation of energy homeostasis. These neuronal groups are under the influence of substances produced by the gastrointestinal tract, such as ghrelin, which activates NPY / AgRP neurons, and insulin or leptin, which activate POMC/CART neurons and inhibit NPY / AgRP neurons [1] (Figure 1).

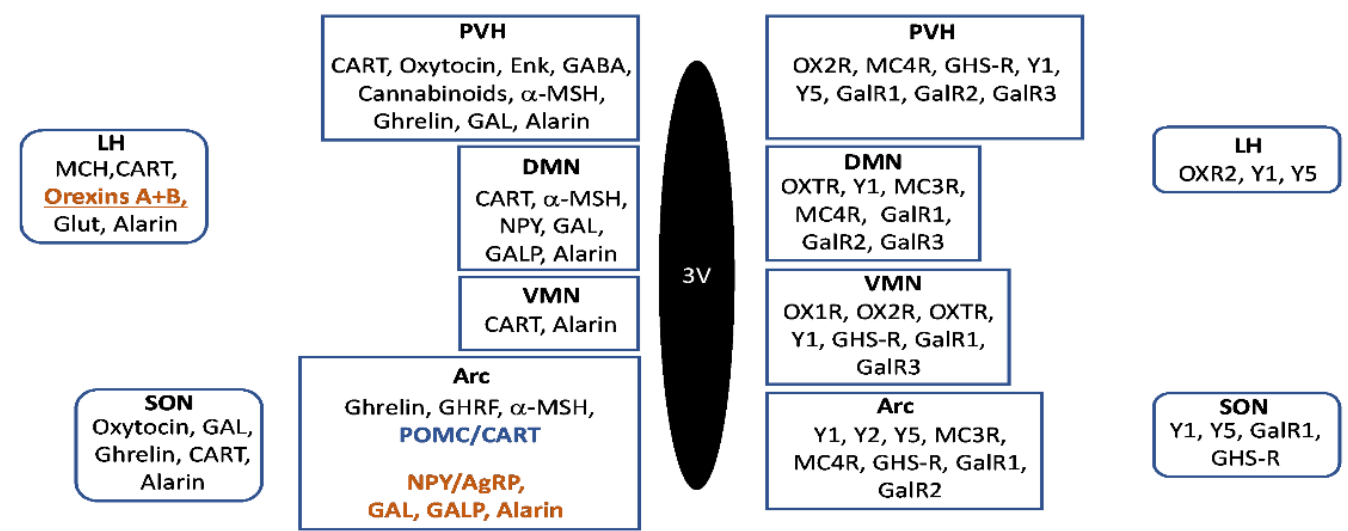

POMC/CART: reduce food intake

NPY/AgRP, GAL, GALP, Alarin, Orexins: stimulate food intake

Figure 1. Schematic representation of the main hypothalamic regions implicated in the control of food intake. Neuroactive substances involved in feeding regulation are represented at the right side of the image, and receptors are represented at the left part of the schema. Abbreviations: 3V-third ventricle; AgRP—agouti-related peptide; Arc — arcuate hypothalamic nucleus; $\alpha$-MSH—alpha-melanocyte stimulating hormone; CART—cocaine and amphetamine regulated transcript; DMN—dorsomedial hypothalamic nucleus; Enk—enkephalins; GABA—gamma-aminobutyric acid; GAL—galanin; GALP— galanin-like peptide; GalR1—galanin receptor type 1; GalR2—galanin receptor type 2; GalR3—galanin receptor type 3; GHRF-growth hormone-releasing factor; Glut-glutamate; GHS-R — growth hormone secretagogue receptor; $\mathrm{LH}$-lateral hypothalamus; MC3R-melanocortin receptor type 3; MC4R-melanocortin receptor type 4; $\mathrm{MCH}$-melanin-concentrating hormone; NPY-neuropeptide Y; OX1R-orexin receptor 1; OX2R-orexin receptor 2; OXTR-oxytocin receptor; POMC-proopiomelanocortin; $\mathrm{PVH}$ - paraventricular hypothalamic nucleus; $\mathrm{SON}$-supraoptic nucleus; VMNventromedial hypothalamic nucleus; Y1-NPY receptor type 1; Y2-NPY receptor type 2; Y5—NPY receptor type 5 .

In addition, other hypothalamic regions and neuropeptides exert different effects on these neuronal groups [2] (Figure 2).

In this regard, it was reported that orexins A and B, synthesized by neurons of the lateral hypothalamus, activate NPY/AgRP neurons located in the hypothalamic arcuate nucleus and that this projection is reciprocal $[3,5]$. Simultaneously, orexins inhibit POMC/CART neurons [1]. The orexigenic effects of orexins are mainly mediated by NPY / AgRP neurons of the arcuate nucleus [2]. Orexins stimulate food intake and NPY expression (but not AgRP) in the arcuate nucleus when administered centrally, and their production is influenced by the nutritional state of the animal and respond to feeding status $[1,2,6]$; thus, the hypothalamic expression of the orexin precursor is increased during fasting $[2,7,8]$. Orexinergic neurons perceive rapidly the body's nutritional status and respond to metabolic signals, such as leptin and ghrelin levels or peripheral blood glucose, since orexin neurons are glucose-sensitive neurons excited by reduced blood glucose levels. Thus, orexin neurons can translate energy status into neural signals [1]; acting on this hypothalamic circuit, they can exert homeostatic regulation [8-10]. In addition, due to their extensive extrahypothalamic projections mainly to the limbic system, forebrain, and midbrain, orexins are involved in the regulation of complex behaviors that regulate food 
consumption, including motivation $[7,8,11]$. The participation of orexins in the stimulation of excessive intake of palatable sweet and fatty foods suggests that these peptides could also promote non-homeostatic dysregulated food intake $[8,9,11]$.

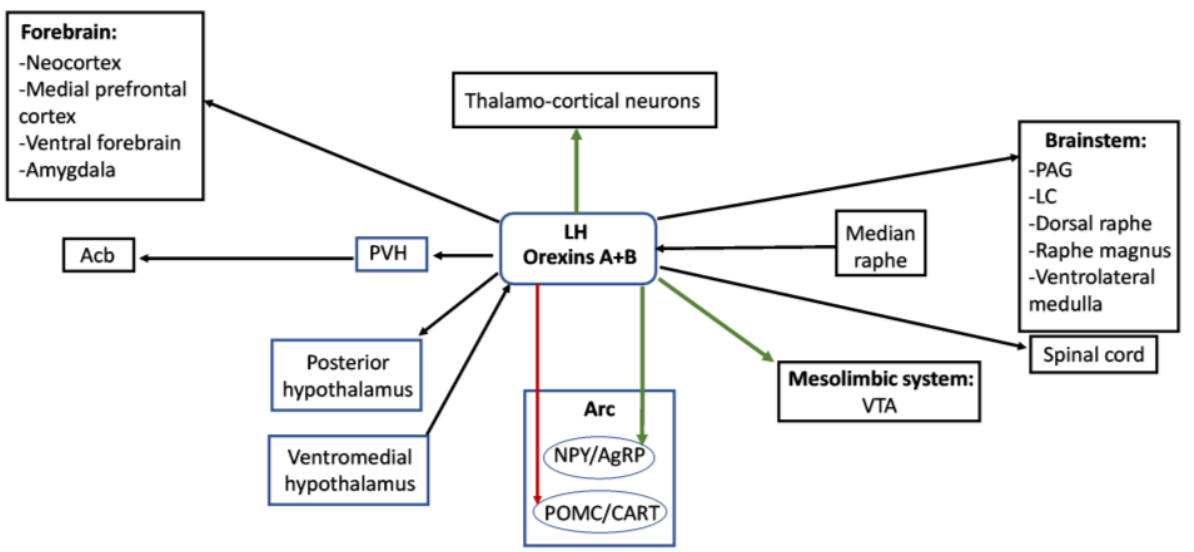

Figure 2. Relationships between different hypothalamic and extrahypothalamic regions involved in the control of feeding. Orexinergic neurons of the lateral hypothalamus send direct projections to other hypothalamic nuclei (posterior hypothalamus), different regions of the brainstem and spinal cord as well as forebrain structures and receive inputs from the median raphe or the ventromedial hypothalamus. Green arrows represent direct activation exerted from the orexinergic neurons to thalamo-cortical neurons, the ventral tegmental area or the NPY / AgRP neurons of the arcuate nucleus, and the red arrow represents the inhibitory projection from orexigenic neurons to POMC/CART neurons of the arcuate nucleus. Abbreviations: Acb-accumbens nucleus; Arc-arcuate hypothalamic nucleus; LC-locus coeruleus; LH-lateral hypothalamus; NPY/AgRP—neurons of the arcuate nucleus containing neuropeptide $\mathrm{Y}$ and agouti-related peptide; $\mathrm{PAG}$ - periaqueductal gray matter; POMC/CART - neurons of the arcuate nucleus containing pro-opiomelanocortin and cocaine- and amphetamine-regulated transcript; $\mathrm{PVH}$ - paraventricular hypothalamic nucleus; VTA—ventral tegmental area.

It was suggested that the primary role of orexins is to promote foraging behavior, with a minimal role in the reinstatement of seeking for food that may be no longer available. In fact, during food deprivation, elevated levels of orexins are detected as well as progressively shorter episodes of sleep and increased locomotor activity as a part of survival strategy $[7,8,12]$. Thus, orexins participate in the regulation of numerous functions $[10,13]$, being the control of food intake and associated behaviors especially relevant within this wide range of activities. Therefore, the aim of this review is to evaluate the role of orexins in this complex mechanism.

\section{Orexins}

Orexins A (hypocretin 1: 33 amino acids) and B (hypocretin 2: 28 amino acids) are excitatory neuropeptides (C-terminally amidated and showing 46\% homology), produced in the lateral hypothalamus/perifornical region and are involved in energy homeostasis, feeding (promote food intake: orexin A has a higher action than orexin B), reward-related appetitive behaviors (mesolimbic pathway), glucose metabolism, motor function, sleep, and wakefulness (during sleep orexin neurons are silent) [14-17] (Table 1). 
Table 1. Orexins: general characteristics.

\begin{tabular}{|c|c|}
\hline Findings & References \\
\hline Excitatory neuropeptides produced in the lateral hypothalamus/perifornical region & [14] \\
\hline $\begin{array}{l}\text { Two adjacent alpha-helices separated by a short } 2-3 \text { amino acids turn. Longer helix: identity region for } \\
\text { both peptides }\end{array}$ & [18] \\
\hline $\begin{array}{l}\text { Involved in energy homeostasis, feeding, reward-related appetitive behaviors, glucose metabolism, } \\
\text { motor function, sleep and wakefulness }\end{array}$ & {$[14-17,19]$} \\
\hline $\begin{array}{l}\text { Orexin A: increase food intake (specially diets rich in saturated fat), decrease tumor development, } \\
\text { excitatory effect on hippocampal neurons; involved in immunomodulatory mechanisms }\end{array}$ & [20-23] \\
\hline Stimulation of hypothalamus-pituitary-adrenal axis. Important sexually dimorphic role & {$[14,24]$} \\
\hline Diurnal orexin variations in the brain of mammals & [15] \\
\hline $\begin{array}{l}\text { Mammalian hypothalamic orexin-producing neurons: anatomically, genetically, and functionally distinct } \\
\text { subpopulations with heterogeneity in neuronal connectivity and gene expression }\end{array}$ & {$[25,26]$} \\
\hline $\begin{array}{l}\text { Neurons expressing orexin of lateral hypothalamus: inputs from arcuate neurons containing AgRP/NPY } \\
\text { and outputs to ventral tegmental neurons (activation of the mesolimbic pathway) and paraventricular } \\
\text { thalamic nucleus }\end{array}$ & {$[13,27,28]$} \\
\hline $\begin{array}{c}\text { Orexinergic neurons project to the medial and posterior hypothalamus, ventral forebrain, amygdala, } \\
\text { neocortex, periaqueductal gray matter, locus coeruleus, dorsal raphe, raphe magnus, ventrolateral } \\
\text { medulla and spinal cord }\end{array}$ & [29] \\
\hline $\begin{array}{l}\text { Orexins / orexin receptors located in adipocytes, thyroid, reproductive tract, pancreas, parathyroid, } \\
\text { adrenal gland, testis, ovary, pituitary and intestines }\end{array}$ & [14] \\
\hline Derived from the prepro-orexin; prepro-orexin gene encoded on chromosome 17q21-q24 in humans & {$[14,29]$} \\
\hline Upregulation in the prepro-orexin mRNA expression during fasting & [6] \\
\hline $\begin{array}{l}\text { Orexin receptors: coupled to G protein. Orexin B: higher affinity for orexin receptor } 2 \text { than for receptor } 1 . \\
\text { Orexin A: equal affinity for both receptors }\end{array}$ & [30] \\
\hline $\begin{array}{l}\text { Orexin receptor: can form homodimers, heterodimers, or oligomers. Orexin A increased } \\
\text { dimerization/oligomerization; antagonists decreased both processes }\end{array}$ & [31] \\
\hline Similar distributions of orexin receptors and melanin-concentrating hormone receptor & {$[29,32]$} \\
\hline Orexin 1 receptor antagonists: inhibited behavioral satiety and hyperphagia mediated by orexin $B$ & [33] \\
\hline Orexin A signaling inhibition: decreased overfeeding from a high fat diet under the condition of satiation & [34] \\
\hline Enhanced orexin 2 receptor signaling: improved leptin sensitivity and prevented diet-induced obesity & [35] \\
\hline Proteins Gq, Gs and Gi: activated by the orexinergic system, with increase in the level of $\mathrm{Ca}^{2+}$ & [36] \\
\hline $\begin{array}{l}\text { Orexin } 1 \text { receptor: activates adenylyl cyclase via a high potency phospholipase } C \text { /protein kinase } C \\
\text { coupling; also coupled to diacylglycerol lipase and phospholipase A2 leading to the production of } \\
\text { 2-arachidonoyl glycerol }\end{array}$ & {$[37,38]$} \\
\hline $\begin{array}{l}\text { Orexin A increased the levels of cyclic adenosine monophosphate and inositol triphosphate and the } \\
\text { labeling of Gi/Gs/Gq but not Go }\end{array}$ & [39] \\
\hline $\begin{array}{l}\text { Orexin receptors: activated the mitogen-activated protein kinase pathway promoting p38 kinase and } \\
\text { extracellular signal-regulated protein kinases } 1 \text { and } 2 \text { phosphorylation }\end{array}$ & [37] \\
\hline
\end{tabular}

Orexin A increases food intake, especially diets that are rich in saturated fat [34] (Table 1), whereas orexin B is less stable and lipophilic than orexin A, which is consistently observed in the cerebrospinal fluid of healthy human individuals [15]. It is known that the orexinergic system stimulates the hypothalamus-pituitary-adrenal axis and that this system regulates intestinal motility and insulin secretion [14] (Table 1). Orexin was also observed in the enteric nervous system and endocrine cells in the gut [20] and it is known that orexin A decreases tumor development [21], exerts an excitatory effect on hippocampal neurons through the orexin 1 receptor [22], and is involved in immunomodulatory mechanisms (e.g., by decreasing the level of pro-inflammatory cytokines) [20] (Table 1). It was reported 
that orexin deficiency regulates cognitive flexibility (ability to adapt behaviors in response to environment changes) in a sex-dependent manner; this means that the peptide plays an important sexually dimorphic role [24] (Table 1). Orexin is involved in the integration of metabolism and sleep: a recent review focused on this topic [19]. It is also known that animals carrying null mutations of the transcription factor named early B-cell factor 2 showed a decrease in the expression of orexin [40]. Recently, the orexinergic system was reviewed in mammalian and non-mammalian species, and it there were reported orexin diurnal variations in the brain of mammals [15] (Table 1).

The lateral hypothalamus regulates metabolism/food intake and integrates hedonic/homeostatic circuits [41]. In the human lateral hypothalamus, cell bodies $(50,000-80,000)$ containing orexin display fusiform/multipolar morphology (20-30 $\mu \mathrm{m}$ in diameter) and show 2-4 dendrites [29]. The hypothalamic distribution of orexin neurons was widely reported in mammals (rat, mouse, hamster, cat, sheep, pig, monkey, and humans) as well as in chicken, amphibians and zebrafish $[15,29,42]$. Neurons containing orexin show heterogeneity in neuronal connectivity and gene expression; this means that mammalian hypothalamic orexin-producing neurons can be segregated into anatomically, genetically, and functionally distinct subpopulations, which are involved in the diverse actions played by these neurons (e.g., reward, stress, emotions, feeding, sleep, and arousal) [25] (Table 1). In this sense, neurochemical heterogeneity (e.g., glutamate, GABA, pro-dynorphin, neuronal activity-regulated pentraxin II, and insulin-like growth factor-binding protein 3) were demonstrated in the hypothalamic neurons expressing orexin $[25,26]$. These neurons also contain the protein delta-like homolog 1 and coexpress several receptors, such as mu opioid, 5-hydroxytryptamine $(\mathrm{HT})_{1 \mathrm{~A}}$, adenosine $\mathrm{A} 1$, leptin, gamma-aminobutyric acid $(\mathrm{GABA})_{\mathrm{A}}$, pancreatic polypeptide $Y 4$ and cholecystokinin A [25,29,43]. To know in-depth this neurochemical diversity is crucial to understand how different neuronal populations are involved in the regulation and coordination of diverse physiological actions (e.g., feeding, and sleep).

In the lateral hypothalamus, neurons expressing orexin receive inputs from arcuate neurons containing NPY/AgRP [27], whereas orexinergic neurons send inputs to ventral tegmental neurons expressing orexin 1 and 2 receptors, and hence orexin activates the mesolimbic pathway $[13,28]$ (Table 1). Moreover, orexinergic lateral hypothalamic neurons send projections to the paraventricular thalamic nucleus, activating the thalamocorticalprojecting neurons located in the latter nucleus (Table 1, Figure 2). Thus, the neuroanatomical connections suggest that orexin regulates attention/arousal to promote reward-related behaviors. In this sense, it is known that orexin controls the rewarding aspect of male sexual reward [44]. Moreover, cell bodies containing orexin project to the posterior hypothalamus (involved in hormone secretion and feeding behavior), medial thalamus, ventral forebrain, amygdala, neocortex, periaqueductal gray matter, locus coeruleus, dorsal raphe, raphe magnus, ventrolateral medulla, spinal cord and brain regions involved in sleep-wake and respiratory/cardiovascular regulation [29] (Table 1, Figure 2).

Thus, orexigenic peptides regulate food intake targeting hypothalamic and extrahypothalamic (e.g., mesolimbic reward circuitry) regions, increasing the complexity to well understand the mechanisms involved in feeding behavior [30]. Orexins or their receptors, in addition to the central nervous system, are located in numerous peripheral tissues, including adipocytes, thyroid, reproductive tract, pancreas, parathyroid, adrenal gland, testis, ovary, pituitary and intestines [14] (Table 1).

\subsection{Orexin Precursor}

In mammals (e.g., rat, dog, pig, human), orexins are derived from the precursor named prepro-orexin (130-131 amino acids); in humans, the prepro-orexin gene is encoded on chromosome 17q21-q24 and show two exons and one intron distributed over 1432 bp [14,29] (Table 1). It is suggested that the gene arose early in the chordate lineage and that it originated from the secretin gene through three genetic rearrangements [45]. Prepro-orexin (130 residues) contains a signal sequence and two well-conserved places for proteolytic maturation followed by a modification of the carboxy-terminal glycines mediated by the 
peptidylglycine alpha-amidating monooxygenase [46]. At present, the enzymes that cleave the prepro-orexin to originate orexins A and B are unknown, although it is suggested that the prohormone convertase 1 could be involved in the processing of the precursor [29]. Orexins A and B show two adjacent alpha-helices (9-14 and 6-7 amino acids long) separated by a short 2-3 amino acids turn; the longer helix is the identity region for both peptides [18] (Table 1). The 19 residues of the $\mathrm{C}$-terminal region of both orexins share 13 identical amino acids [29]. During fasting, an upregulation in the prepro-orexin mRNA expression was reported [6] (Table 1). Finally, it is known that the promoter region of the prepro-orexin gene has two early B-cell factor 2 binding sites, named olf- 1 sites, that a deletion of the olf1-site proximal to the transcription start site of the gene increases the expression of the prepro-orexin gene, and that a deletion of the distal olf1-like site decreases its expression [40].

\subsection{Orexin Receptor}

Two orexin receptors highly conserved across species are described: orexin 1 and orexin 2. Rat and human orexin 1 and 2 receptors show, respectively, $94 \%$ and $95 \%$ homology. Orexin B shows a higher affinity for orexin receptor 2 than for orexin receptor 1, whereas orexin A shows equal affinity for both receptors [30] (Table 1). Both orexin receptors are $\mathrm{G}$ protein-coupled receptors (Table 1): orexin 1 receptor is abundant in the spinal cord, laterodorsal tegmentum, locus coeruleus, dorsal raphe, hypothalamus (ventromedial region), paraventricular thalamic nucleus, hippocampus (CA2 region) and prefrontal cortex, whereas the orexin 2 receptor is prominent in the neocortex, central amygdala, hippocampus (CA3 region), septum, thalamus, and hypothalamus (dorsomedial region) [29]. The orexin receptor can form homodimers, heterodimers or oligomers and it was reported that orexin A increased the dimerization/oligomerization, whereas antagonists decreased both processes [31] (Table 1). For example, orexin 1 and corticotropin-releasing factor receptor dimerization and orexin 1 receptor and kappa opioid receptor heteromerization were reported [31]. In general, the distribution of orexin receptors and fibers containing the peptide was similar, and it is known that the distribution of the orexin receptors was similar to that observed for the melanin-concentrating hormone receptor [29,32] (Table 1). Orexinergic terminals show two bouton types: large (ovoid, diameter: $>1.4 \mu \mathrm{m}$ ) or small (spherical, $<1.4 \mu \mathrm{m}$ ) [15].

It is known that animals without the orexin 2 receptor had slow cessations of movements (sleep attacks), whereas those lacking the orexin 1 receptor showed disrupted sleep but fewer signs of sleep attacks [47]. In the medulla oblongata, it was reported that chronic aldosterone exposure and salt intake did not change the expression of both orexin 1 and 2 receptors; however, in the hypothalamus, the expression of the latter receptor was increased [48]. It is also known that orexin 1 and 2 receptors are involved in the control of body weight and energy metabolism [14]. During the estrus cycle, it was reported that the expression of orexin receptors was increased exclusively during proestrus and that the administration of orexin receptor antagonists blocked ovulation as well as the effects mediated by the follicle-stimulating and luteinizing hormones [49]. The administration of orexin 1 receptor antagonists inhibited behavioral satiety and hyperphagia mediated by orexin B [33], and the inhibition of the orexin A signaling decreased overfeeding from a high fat diet under the condition of satiation. This means that orexin A regulates unconditioned reward-based high fat feeding, and that the peptide is involved in the modulation of cognitive-emotional mechanisms [34] (Table 1). Recently, a subtype-selective orexin 1 receptor antagonist was developed, showing the potential of structure-based drug designs to obtain new selective ligands for the orexin receptors [50] and it was reported that the neural depolarization mediated by orexin A depended on non-selective cation channels [51]. It was demonstrated that an enhanced orexin 2 receptor signaling improved leptin sensitivity and prevented diet-induced obesity [35] (Table 1).

It is known that dynein light chain Tctex-type 1 and beta-arrestin are coupled to the C-terminus of the orexin receptor and it seems that the extracellular portion of the receptor contributes to the binding of the peptide [31,52-54]. The signaling pathways activated by 
the orexinergic system remains obscure, although it is known that proteins Gq, Gs and $\mathrm{Gi}$ are activated and that an increase in the level of $\mathrm{Ca}^{2+}$ occurs [36] (Table 1). Orexin 1 receptor activates adenylyl cyclase via a high potency phospholipase $\mathrm{C}$ /protein kinase $C$ coupling and a low potency Gs coupling [38] (Table 1). In fact, the response of orexin was blocked when inhibitors of phospholipase $C$ or protein kinase $C$ were used [55]. The orexin 1 receptor is also coupled to diacylglycerol lipase (DAGL) and phospholipase A2 leading to the production of 2-arachidonoyl glycerol [37] (Table 1). Orexin A increased the levels of both cAMP (cyclic adenosine monophosphate) and IP3 (inositol triphosphate) and the labeling of Gi/Gs/Gq but not Go [39] (Table 1). Orexin B also increased the level of cAMP and it was reported that food deprivation exerted a differential effect regarding the coupling that occurred between different $G$ proteins and orexin receptors [14]. The action mediated by orexin was sensitive to inhibitors of protein kinase A mediating the cAMP effect [29]. The activation of both receptors activated the mitogen-activated protein kinase (MAPK) pathway, promoting p38 kinase and extracellular signal-regulated protein kinases (ERK) 1 and 2 phosphorylation [31] (Table 1).

\subsection{Physiological Actions Mediated by Orexins}

The administration of orexin increases food intake and wakefulness, regulates locomotor activity, hormone secretion, emotional states (anxiety, panic), cognition and blood pressure and suppresses rapid eye movement sleep [15,29] (Table 2).

Table 2. Orexins: physiological actions and pathological conditions.

\section{Findings}

References

Increases wakefulness and suppresses rapid eye movement sleep. Narcolepsy occurs when the orexin 2

receptor gene is inactivated. Narcolepsy: a decrease in the level of orexin (cerebrospinal fluid) and no or a few orexinergic neurons were observed in the hypothalamus

$[15,29,31]$

Increases food intake; regulates locomotor activity, placental development and growth hormone secretion, emotional states, cognition, body temperature, pain and blood pressure

$[15,29,31]$

Adipose tissue: orexins A and B increased peroxisome proliferator-activated receptor-gamma-2 expression; decreased expression of hormone-sensitive lipase enzyme

Orexin A: decreased glycerol release, promoted acid secretion, decreased the rate of gastric emptying and

plasma leptin level. A fat diet and triglycerides stimulated orexin tone. Orexin A release depends on a low glucose level

Lacking leptin receptors (obese animals): more widespread distribution of orexins in the central nervous system than in lean animals

Orexins: increased motility of gastrointestinal tract, involved in glucose metabolism. Fasting: increased the level of phosphorylated cAMP response binding protein in neurons expressing orexin

$[59,60]$

Orexin A: increased plasma levels of adrenocorticotropic hormone and corticosterone and mRNA levels of steroidogenic enzyme. Action limited to a short-term due to increased wakefulness

$[29,61,62]$

Involved in the maintenance of normal insulin sensitivity with advanced age. Crucial in maintaining the hypothalamic insulin signaling

Hyperglycemia blocked the expression of orexin. Hypoglycemic animals: higher hypothalamic level of orexin B than in controls

Orexins A and B promoted and inhibited respectively the proliferation of 3T3-L1 cells showing an adipocyte-like phenotype. Both orexins increased plasma levels of norepinephrine

Orexins A and B: increased energy expenditure and food consumption. Fasting animals: increased hypothalamic level of prepro-orexin

Perifornical area or lateral hypothalamus: orexin A administration increased food intake. A long-term administration of orexin A did not modify daily food intake, level of glucose in blood and body weight

Orexin A increased more the metabolic rate than orexin B. Stimulation of metabolic rate by orexin A lower during the light cycle than during the dark ones 
Orexins are involved in endocrine (controlling the release of luteinizing hormone, and corticotropin-releasing hormone), autonomic (blood pressure, body temperature, heart rate, and breathing) and pain (decrease) actions [29]. In addition, orexin is involved in placental development and growth [15] and in the release of glucocorticoids [31]. Orexins regulate the brain reward function, and it seems that this is mediated by opioids involved in motivational mechanisms [29]. Narcolepsy occurs when the orexin 2 receptor gene is inactivated; in humans, individuals suffering from narcolepsy show a decrease in the level of orexin in the cerebrospinal fluid, and no or a few orexinergic neurons are observed in the hypothalamus [29] (Table 2).

In the adipose tissue, both orexins A and B increased PPAR (peroxisome proliferatoractivated receptor)-gamma-2 expression, which is involved in adipose differentiation and decreased the expression of the hormone-sensitive lipase enzyme [56] (Table 2). In addition, orexin A decreased the release of glycerol, suggesting that the peptide regulates fat metabolism by inhibiting lipolysis [56] (Table 2). It is also important to note that orexins A and B promoted and inhibited, respectively, the proliferation of 3T3-L1 cells, which show an adipocyte-like phenotype [14] (Table 2). It was reported that the distribution of orexins in the central nervous system of obese animals lacking the leptin receptor was more widespread than that observed in lean animals [58] (Table 2). This is due to the lack of leptin receptors since leptin negatively regulates the expression of orexin and hence, the orexin tone is augmented in obese individuals [66]. It is also known that a fat diet and triglycerides stimulate orexin tone [57] (Table 2).

It was reported that orexins increase the motility of the gastrointestinal tract, that are involved in glucose metabolism, and that in neurons expressing orexin, fasting increased the level of pCREB (phosphorylated cAMP response binding protein) $[59,60]$ (Table 2). It is also known that orexin A promoted the acid secretion and decreased the rate of gastric emptying and plasma leptin level [14] (Table 2). It was demonstrated that the neuroendocrine regulatory peptide- 2 regulated both gastric emptying and secretion and that these mechanisms were mediated by the orexin system [67].

Orexin A increased the plasma level of adrenocorticotropic hormone and corticosterone, but this effect was not observed with orexin B [61] (Table 2). Both orexins increased the plasma level of norepinephrine, suggesting that the peptides stimulated the adrenal medulla [14] (Table 2). Orexin A increased the release of cortisol and mRNA levels of CYP11B1/B2, CYP21 and HSD3B2 (steroidogenic enzymes), but the levels of other enzymes, such as CYP11A and CYP17, were not affected [62] (Table 2). Protein kinase C and ERK 1/2 (extracellular signal-regulated protein kinases 1 and 2) are also involved in these mechanisms mediated by orexin A. This orexin also decreases the level of circulating TSH (thyroid-stimulating hormone), although several studies have shown that orexin A does not exert a significant action on the thyroid-pituitary axis [14]. In avian liver, it was reported that hepatocytes express/secrete orexin and that orexin A regulates hepatic lipogenesis via activation of the ERK1/2 signaling pathway [68].

In humans, orexin A is colocalized with insulin in the pancreatic islets, and the release of orexin A is dependent on a low glucose level; this means that the peptide regulates the secretion of the pancreatic hormones and glucose modulation [60] (Table 2). Orexin plays an important role in the maintenance of normal insulin sensitivity with advanced age, and the data show that the peptide is crucial in maintaining the hypothalamic insulin signaling that is responsible for the prevention of the onset of peripheral insulin resistance, which tends to increase with age [63] (Table 2). This could explain why diabetes (type 2) incidence is augmented in normal weight individuals showing a deficiency in orexin. Hyperglycemia blocks the expression of orexin, and it was reported that the circadian clock of the suprachiasmatic nucleus could be reset through arousal promoting signals from neurons containing orexin [60] (Table 2). In hypoglycemic animals, the hypothalamic level of orexin B was higher than in control animals [64] (Table 2).

Orexins A and B increase food consumption and, in fasting animals, the level of preproorexin also increased in the hypothalamus [6] (Table 2). The administration of orexin A 
into the perifornical area or lateral hypothalamus increased food intake. It is known that neurons containing orexin are sensitive to the levels of triglyceride, leptin, and glucose [29] (Table 2). It is important to note that a long-term administration of orexin A did not modify daily food intake, the level of glucose in blood, and body weight, suggesting that the actions of orexin A could be limited to the short-term, due to increased wakefulness [29] (Table 2). In this sense, orexin knockout animals showed very modest differences in food intake, and animals depleted of neurons expressing orexin showed obesity and hypolocomotion [69,70]. However, other studies showed contradictory results since the genetic ablation of the lateral hypothalamic neurons containing orexin led to hyperphagia and obesity; this means that orexin is a key regulator to maintain a stable energy homeostasis [69]. These and other data suggest that the food effects mediated by orexins result from arousal rather than from a direct feeding pressure [29].

Orexins A and B increase energy expenditure. It was reported that orexin A increased more the metabolic rate than orexin $\mathrm{B}$, and that the stimulation of the metabolic rate by orexin A was lower during the light cycle than during the dark ones [65] (Table 2). Moreover, the administration of orexin A into the paraventricular hypothalamic nucleus increased energy expenditure and physical activity [65]. Orexin A controls the operant that responds to palatable food rewards [71], and it is known that the action of orexin in the mesolimbic system is needed for an opioid-induced high-fat diet [72]. There are data suggesting that orexin A modulates emotional/cognitive processes (e.g., motivation to obtain food) and it was reported that expectation for food reward (both palatable (chocolate) and general (chow)) activated lateral hypothalamic neurons containing orexin and other brain regions involved in feeding control [34] (Table 2). Finally, it is known that orexin A is involved in compulsive behaviors indicating that the orexin 1 receptor is implicated in obsessive-compulsive disorders [73] (Table 2).

\section{Orexins and Food Intake in Experimental Animal Models}

\subsection{Rat}

In male and female rats, the administration of genistein (a phytoestrogen) from postnatal days 6 to 13 was studied regarding the expression of orexin in the hypothalamus (lateral, dorsomedial, and perifornical areas) [74]. No alteration in orexin expression was observed, and hence it seems that genistein does not regulate such expression in both sexes. However, sex differences in the demand for highly palatable food (higher in females than in males) were demonstrated; it seems that these differences are related with sexual dimorphism in the actions exerted by the orexinergic system [75] (Table 3).

Table 3. Orexins and food intake: experimental animal models.

\begin{tabular}{|c|c|c|}
\hline Effects & Species & References \\
\hline \multicolumn{3}{|l|}{ Obesity/high-fat diet } \\
\hline $\begin{array}{l}\text { Perinatal maternal high-fat diet: increased hypothalamic projections to lateral } \\
\text { hypothalamus orexinergic neurons and basal activation of these neurons }\end{array}$ & Rat & [41] \\
\hline $\begin{array}{l}\text { Palatable high-fat diet: time-dependent synaptic plasticity in orexinergic neurons located } \\
\text { in the lateral hypothalamus }\end{array}$ & Rat & [76] \\
\hline $\begin{array}{l}\text { Intestinal electrical stimulation: modified hypothalamic orexin expression in lateral } \\
\text { hypothalamus, ameliorated a diet-induced obesity }\end{array}$ & Rat & [77] \\
\hline $\begin{array}{l}\text { Obesity development: variation of orexin expression. Differential roles in food } \\
\text { consumption at different feeding periods }\end{array}$ & Rat & [78] \\
\hline $\begin{array}{l}\text { High-fat diet: activation of neurons expressing orexin and increase in consumption of a } \\
\text { high-fat diet by activating the mesolimbic reward pathway }\end{array}$ & Rat & [79] \\
\hline $\begin{array}{l}\text { Obese animals: a deficiency in orexins promote behavioral changes. Impaired activity of } \\
\text { neuronal networks by a decrease in the action medited by orexin }\end{array}$ & Mouse & [80] \\
\hline $\begin{array}{l}\text { Orexin A: decreased adiposity, intraperitoneal fat deposit and expression of several } \\
\text { receptors in the brain. Not effect on glucose metabolism and energy expenditure }\end{array}$ & Mouse & [21] \\
\hline
\end{tabular}


Table 3. Cont.

\begin{tabular}{|c|c|c|}
\hline Effects & Species & References \\
\hline \multicolumn{3}{|l|}{ Feeding } \\
\hline $\begin{array}{l}\text { Central nucleus of the amygdala: orexin A increased gastric motility and palatable food } \\
\text { intake }\end{array}$ & Rat & [81] \\
\hline $\begin{array}{l}\text { Posterior paraventricular thalamus: regulation of hunger-related signals in nucleus } \\
\text { accumbens core. Sucrose feeding increases dopamine release in nucleus accumbens shell }\end{array}$ & Rat & {$[82,83]$} \\
\hline $\begin{array}{l}\text { Chronic intake of fructose: increased orexin A level in hypothalamus and ventral } \\
\text { tegmental area }\end{array}$ & Rat & [84] \\
\hline $\begin{array}{l}\text { Feeding (rest phase): decrease in the activation of hypothalamic lateral neurons } \\
\text { expressing orexin }\end{array}$ & Rat & [85] \\
\hline Decreased orexin A plasma level after four weeks of time-restricted feeding regimen & Mouse & [86] \\
\hline \multicolumn{3}{|l|}{ Sexual dimorphism } \\
\hline Higher demand in females than in males for highly palatable food & Rat & [75] \\
\hline \multicolumn{3}{|l|}{ Receptors } \\
\hline $\begin{array}{l}\text { Decrease of sensitivity to gastrointestinal nutrient load and more consumption of } \\
\text { food-hindbrain orexin } 1 \text { receptors }\end{array}$ & Rat & [87] \\
\hline $\begin{array}{l}\text { Administration of sea buckthorn seed oil: increase of orexin A levels and expression of } \\
\text { orexin } 1 \text { receptors in hypothalamus and brainstem }\end{array}$ & Rat & [88] \\
\hline $\begin{array}{l}\text { Orexin } 1 \text { receptor-deficient animals resistant to diet-induced obesity and food } \\
\text { consumption }\end{array}$ & Mouse & [89] \\
\hline $\begin{array}{c}\text { Orexin } 2 \text { receptor-deficient animals: less energy expenditure when consumed a high-fat } \\
\text { diet }\end{array}$ & Mouse & [89] \\
\hline \multicolumn{3}{|l|}{ Others } \\
\hline $\begin{array}{l}\text { Orexinergic system: mediation of age-related deficits in behavioral/neurochemical } \\
\text { mechanisms of feeding }\end{array}$ & Rat & [90] \\
\hline Prazosin: motivational response of food consumption through orexinergic system & Rat & [91] \\
\hline Animals lacking dynorphin peptides: decrease in orexin A hypothalamic level & Mouse & [92] \\
\hline Increased orexin hypothalamic expression in pinealectomized animals & Rat & [93] \\
\hline $\begin{array}{l}\text { Orexin A: improved glucose control by protecting beta-cells from apoptosis and by } \\
\text { increasing the sensitivity to insulin }\end{array}$ & Rat & [94] \\
\hline Bilateral nephrectomized animals: orexin involved in anorexia development & Rat & [95] \\
\hline
\end{tabular}

In the central nucleus of the amygdala, the administration of orexin A increases gastric motility and palatable food intake; in addition, the lateral hypothalamus, nucleus accumbens and ventral tegmental area are also involved in the intake [81] (Table 3). It was reported that orexin, in the posterior paraventricular thalamus (which receives a strong orexinergic innervation), regulates hunger-related signals in the nucleus accumbens core [82] and that the peptide increases the release of dopamine in the nucleus accumbens shell by sucrose feeding [83] (Table 3). It is known that a palatable high-fat diet promotes time-dependent synaptic plasticity in the neurons expressing orexin or melanin-concentrating hormone located in the lateral hypothalamus [76] (Table 3). After the administration of this diet, orexin neurons show a transient increase in spontaneous excitatory transmission, which return to control levels with prolonged feeding, whereas melanin-concentrating hormone neurons show a delayed increase in excitatory synaptic transmission, which progressively increase as the palatable high-fat diet becomes chronic [76]. It seems that the changes observed in the synaptic properties of these neurons are due to the number of active synaptic contacts/altered postsynaptic sensitivity depending on feeding duration and cell type [76]. However, this diet does not induce changes in the inhibitory transmission in both nerve cell types at any time point [76]. The results suggest that the actions of a palatable high-fat diet 
on feeding-related nerve cells are dynamic and specific for each type of neuron. However, it was also demonstrated that orexinergic neurons (orexin A) shows an endocannabinoidmediated disinhibition due to an increase in the inhibitory cannabinoid receptor type 1 positive puncta versus the excitatory ones [96]. In obese animals, the activation of the cannabinoid receptor type 1 decreases the inhibition of the orexinergic neurons and hence increases the release of orexin A, promoting hyperphagia and body weight [96]. The latter study showed that obesity-driven synaptic remodeling affects the endocannabinoid control of neurons containing orexin [96]. It was also reported that a perinatal maternal high-fat diet increases the hypothalamic projections (e.g., from the ventromedial hypothalamus) to the lateral hypothalamus containing neurons expressing orexin $\mathrm{A}$ as well as the basal activation of these neurons [41] (Table 3). A responsiveness of lateral hypothalamic neurons to leptin was also observed [41]. Because nerve cells located in the lateral hypothalamus send projections to dopaminergic neurons located in the ventral tegmental area, it seems that these hypothalamic nerve cells are involved in early dietary programming of the mesocorticolimbic reward circuits.

In rats, it was reported that the intestinal electrical stimulation modifies the hypothalamic expression of orexin in the lateral hypothalamus and ameliorates diet-induced obesity [77] (Table 3). Electrical stimulation decreases food intake, body weight and the expression of orexin and improves insulin sensitivity and glucose tolerance. Lateral hypothalamic neurons expressing orexin send projections to the medial prefrontal cortex, and it was demonstrated that for a cue-potentiated feeding, it is necessary the activation of the orexin 1 receptors located in the medial prefrontal cortex, the connectivity of the latter region with the lateral hypothalamus and the development of the medial prefrontal cortex neural plasticity [97]. The data show the involvement of the medial prefrontal cortex in the cognitive motivation to eat, suggesting that this cortical region is a potential target for the treatment of excessive appetite/overeating. It was reported that the administration of orexin A into the hindbrain increased both meal size and feeding; these effects were inhibited with the orexin 1 receptor antagonist SB-334,867; and hypothalamic neurons containing orexin send projections to hindbrain centers (e.g., area postrema, and nucleus of the solitary tract) in which the expression of the orexin 1 receptor was reported [87]. The study showed that, via the hindbrain orexin 1 receptors, hypothalamic neurons expressing orexin decrease the sensitivity to gastrointestinal nutrient load and hence, more food is consumed [87] (Table 3).

In female rats, it was reported that a cafeteria diet promoted changes in the hypothalamic mechanisms involved in food consumption at different periods (short-, medium- and long-term) [78]. A short-term period (4 weeks of cafeteria diet) did not affect the expression of orexin in the hypothalamus; a medium-term period (11 weeks) increased the expression of orexin and body weight, and a long-term period ( 20 weeks) increased more such expression [78]. The alteration in mRNA orexin level was associated to epigenetic modifications in the promoter region. Thus, the data indicate that during the development of obesity, the expression of orexin varies, and hence the alterations observed show the differential roles played by orexin in food consumption at different feeding periods (Table 3). Moreover, the administration of sea buckthorn seed oil was studied regarding the cisplatin-induced vomiting and the role played by orexin A [88]. The plasma level of orexin A and mRNA/protein expressions of the orexin 1 receptor were measured in the brainstem/hypothalamus as well as the expression of orexin A in the lateral hypothalamus. In all cases, the administration of sea buckthorn seed oil increased significantly all the parameters studied and prevented cisplatin-induced vomiting. Thus, it seems that this prevention was mediated by an increase in the central and peripheral levels of orexin A and in the expression of the orexin 1 receptor in both the hypothalamus and brainstem [88] (Table 3). A high-fat diet activates neurons expressing orexin, which in turn, increases the consumption of a high-fat diet by activating the mesolimbic reward pathway [79] (Table 3). It was reported that under a palatable high-fat Western diet (short-term), excitatory synapses to orexin neurons became amenable to long-term depression after one week of high-fat diet feeding; the effect was re- 
versed after four weeks of a high-fat diet [79]. It seems that this mechanism is a homeostatic response that occurs to prevent the overactivation of such neurons and to decrease high-fat diet consumption and obesity. The long-term depression depends on the retrograde endocannabinoid signaling and on the postsynaptic metabotropic glutamate receptor 5 [79]. In free-feeding animals, it was demonstrated that the administration into the median raphe nucleus of prazosin ( $\alpha 1$-adrenoceptor antagonist) increased food intake and the expression of fos in the lateral hypothalamic neurons containing orexin [91]. It was also demonstrated that the latter neurons are targeted by axons arising from cell bodies located in the median raphe nucleus [91]. The findings suggest that prazosin, through the orexinergic system, promotes a motivational response regarding food consumption (Table 3).

It was reported that a chronic intake of fructose increases the level of orexin $\mathrm{A}$ in the hypothalamus and ventral tegmental area [84] (Table 3). This means that hypothalamic orexinergic neurons are activated by this consumption. It is known that melatonin decreased adiposity, body weight and food intake [93]. In pinealectomized animals, it was found that the hypothalamic expression of orexin was increased, but when these animals were treated with melatonin, such expression was reduced [93] (Table 3). In bilateral nephrectomized rats, food intake decreased significantly, and it was reported that hypothalamic mRNA level of orexin was lower in bilateral nephrectomized rats than in sham-operated animals [95]. This finding suggests that orexin could be involved in the development of anorexia in bilateral nephrectomized rats (Table 3). In rats suffering from type 2 diabetes, glucose regulation was improved after a chronic treatment with orexin A [94]. In addition, the peptide attenuated the loss of pancreatic $\beta$-cells by apoptotic mechanisms, increased insulin sensitivity and decreased plasma tumor necrosis factor- $\alpha$ and non-esterified fatty acid levels [94]. In sum, orexin A improved glucose control by protecting beta-cells from apoptosis and by increasing the sensitivity to insulin (Table 3).

During the rest phase, it was reported that feeding decreased the activation of the hypothalamic lateral neuron expressing orexin in the light [85] (Table 3). It is known that aging is related to homeostatic changes (e.g., food innate) and to a dysregulation/loss of the orexinergic system [90]. Aged rats had slower feeding latencies, and this was ameliorated when the orexin expression was upregulated [90]. In the insular cortex of aged rats, this upregulation did not restore deficits in feeding-elicited release of neurotransmitters (e.g., GABA, glutamate, and acetylcholine) but enhanced basal neurotransmitter levels. This means that the orexinergic system mediates age-related deficits in the behavioral/neurochemical mechanisms of feeding and that an increase in the action of this system is a potential strategy to improve both cognitive/physiological functions in age-related disorders (Table 3).

\subsection{Mouse}

In mice lacking dynorphin peptides, a significant decrease in the hypothalamic level of orexin A was reported; this decrease was particularly observed in animals that received a high-fat diet and were under ad libitum condition [92] (Table 3). Orexin 1 receptor-deficient animals were resistant to diet-induced obesity and food consumption was similar between high-fat and chow food, whereas orexin 2 receptor-deficient animals showed less energy expenditure when they consumed a high-fat diet [89] (Table 3). The latter study also demonstrated that nerve cells expressing orexin are involved in the interactive action of exercise and diet on body weight gain and that orexin-deficient mice have normal brown adipose tissue. The results suggest that orexin 1 and 2 receptors exert a unique role in energy metabolism (Table 3).

It was reported that after four weeks of time-restricted feeding regimen, the plasma level of orexin A decreased; this means that this regimen regulated the expression of orexin A [86] (Table 3). In the lateral hypothalamus, no altered mRNA expression of orexin was observed in mice exposed to transient peripubertal diet-induced obesity [98]. In obese animals, a deficiency in orexins could be the cause of behavioral changes (decreased reward seeking, altered stress response, and lowered arousal) [80]. In fact, the activity of neuronal 
networks (hippocampus and lateral hypothalamus) was impaired when a decrease in the action mediated by orexin occurred [80] (Table 3). Finally, in mice, it was reported that orexin A decreased adiposity, intraperitoneal fat deposit and the expression of several receptors in the brain but did not affect glucose metabolism and energy expenditure [21] (Table 3).

The relationships between eating and orexinergic neurons were studied [99]. It was suggested that, when these neurons are active, eating is less likely to occur. It was reported that after eating onset, the activity of the orexinergic neurons decreased, and during eating, they remained in a down state [99]. This was observed in fasted and fed mice that received calorie-free food and foods of diverse textures/tastes, suggesting that the inactivation of the orexinergic neurons was due to the act of eating itself [99]. In the same study, the authors reported that in orexinergic-neuron-deficient mice, overweight was observed and the weight gain was prevented by mild caloric restriction [99]. The authors concluded that the activity of the orexinergic neurons can be regulated by a voluntary action, such as eating, and that it is irrespective of the food nature.

\subsection{Nonhuman Primates}

Maternal high-fat diet consumption resulted in increased hedonic feeding that was associated with decreased dopaminergic fibers and receptors in the prefrontal cortex, but the post-weaning consumption of high-fat diet also altered the reward neurocircuitry in nonhuman primates [100]. It was reported a decrease in the orexinergic hypothalamic projections to the rostral ventral tegmental area; this alteration may be programmed developmentally, although the possible alteration of the dopaminergic signal by orexigenic projections remains to be established [100]. In sum, both maternal and post-weaning consumption of high-fat diet may alter the neural circuits regulating reward and increase hedonic feeding in offspring, possibly through the contribution of multiple organ systems [100].

\section{Orexins and Food Intake in Humans}

In humans, feeding behavior is complex since some hypothalamic nuclei are involved in the regulation of food intake, stress response and rewards and, in addition, exert effects on the reward system, cortex or brainstem [4,5,101] (Table 4).

Table 4. Orexins and food intake: humans.

\begin{tabular}{|c|c|}
\hline Findings & References \\
\hline $\begin{array}{l}\text { Complex feeding behavior; involvement of some hypothalamic nuclei in regulation of food intake, stress response and } \\
\text { rewards and exert effects on the reward system, cortex, or brainstem }\end{array}$ & {$[4,5,101]$} \\
\hline $\begin{array}{c}\text { Frequent link between overweight and psychological problems; bridge between certain hypothalamic nuclei towards the } \\
\text { appetite-regulating orexigenic system. Reward signaling encoded by orexins }\end{array}$ & {$[100,101]$} \\
\hline $\begin{array}{c}\text { Orexin level in cerebrospinal fluid higher at night-time and lowest at midday. Orexin A level correlated negatively with } \\
\text { body weight; not related to body adiposity }\end{array}$ & {$[102,103]$} \\
\hline $\begin{array}{c}\text { Orexin A peaked once or more during the whole day. No discernible pattern with eating, wake or sleep (healthy } \\
\text { male volunteers) }\end{array}$ & [103] \\
\hline Obese individuals: orexin A plasma level lower than lean individuals & [104] \\
\hline $\begin{array}{c}\text { Orexin A plasma level: correlated positively to body mass index. Intermittent daily fasting increased peptide plasma level } \\
\text { during fasting hours }\end{array}$ & {$[103,105]$} \\
\hline $\begin{array}{l}\text { Southwestern American Indians: genetic variant of the HCRTR1 gene (gene linked to sleep regulation and feeding). } \\
\text { Regulation of hypothalamic-pituitary-adrenal axis by HCRTR1/hypocretin (orexin receptor/orexin) system. Axis } \\
\text { disruption: high cortisol levels, overeating, night eating syndrome }\end{array}$ & [106] \\
\hline $\begin{array}{l}\text { Alzheimer's disease and Parkinson's disease patients: decrease in number of hypothalamic neurons containing orexin and } \\
\text { in orexin level in the cerebrospinal fluid }\end{array}$ & [107] \\
\hline $\begin{array}{c}\text { Patients with depression: lower levels of orexin A in their cerebrospinal fluid; the higher depression scores, the lowest } \\
\text { levels of orexin A }\end{array}$ & [105] \\
\hline Schizophrenic patients: higher levels of orexin A compared to controls & [105] \\
\hline $\begin{array}{l}\text { Patients with chronic schizophrenia: body mass index positively related with orexin A levels and negatively related with } \\
\text { negative symptoms. Orexin A levels might modify metabolic indexes to increase the rates of overweight and obesity }\end{array}$ & [105] \\
\hline
\end{tabular}


Some of these hypothalamic nuclei form a bridge toward the appetite-regulating orexigenic system [101], and reward signaling is encoded in part by neuropeptides, such as orexins [100]; thus, a link between overweight and psychological problems is very frequent (Table 4). Stress is one of the most common problems since it can cause a weight/fat increase, but also a decrease in these parameters in individuals who keep their stress response with less energy intake. Two important stress systems are the hypothalamic-pituitary-adrenal axis and the autonomic nervous system. The prolonged activation of these systems by chronical stress leads to detrimental physiological consequences, often associated with diet alterations. Chronic psychosocial stress may cause uncontrolled eating ranging from emotional eating in response to negative emotions to disinhibition or external eating (eating because food is available) up to binge eating (recurrently eating too much food because of perceiving a lack of control), all of them leading to overweight [101]. These behaviors are also dependent on age; a higher prevalence of stress-eating behaviors was reported in youths compared to adults, being that adolescence is the critical period for the onset of eating disorders [101].

In humans, it was reported that the level of orexin in the cerebrospinal fluid varies; thus, it is higher at night-time and lowest at midday [102] (Table 4). In this fluid, the level of orexin A is correlated negatively with body weight, but it is not related to body adiposity [103] (Table 4). Concerning the plasmatic levels, the diurnal levels of orexin A varied greatly between subjects. In healthy male volunteers, it was reported that orexin A peaked once or more during the whole day within different subjects with no discernible pattern with eating, wake or sleep when compared between subjects [103] (Table 4). It seems that acute feeding does not affect the plasma concentrations of orexin A in healthy subjects; thus, it is unclear if plasma orexin may have physiological significance as related to autonomic and neuroendocrine rhythms [103]. In obese individuals, the plasma level of orexin A was lower than that found in lean individuals [104] (Table 4). Plasma levels of orexin A correlated positively to body mass index (BMI), and intermittent daily fasting increased these plasmatic levels during fasting hours in healthy male volunteers [103] (Table 4).

Feeding and waking are closely associated with one another. Night eating syndrome, which predicts body weight gain, is believed to have a genetic component. Southwestern American Indians exhibit an elevated risk of obesity; with a group of this population in a clinical setting for night eating, a genetic variant of the HCRTR1 locus was reported [106]. This gene is linked to sleep regulation and feeding, and it was suggested that the HCRTR1/hypocretin (orexin receptor/orexin) system might regulate the hypothalamicpituitary-adrenal axis. Thus, a disruption in this axis produced by variants of the abovementioned gene could be involved in high cortisol levels and overeating as well as in night eating syndrome [106], although further studies with more participants are needed to confirm this hypothesis (Table 4).

Patients suffering from advanced Alzheimer's disease showed an important decrease $(40 \%)$ in the number of hypothalamic neurons containing orexin and in the level of orexin in the cerebrospinal fluid (14\%) [107] (Table 4). Similar results were found in Parkinson's disease: $25 \%$ reduction in the cerebrospinal fluid and $40 \%$ in the number of cell bodies [107] (Table 4). In fact, the prepro-orexin gene might be a candidate for a group of neurodegenerative disorders collectively called "chromosome 17-linked dementia", including the disinhibition-dementia-parkinsonism-amyotrophy complex and pallido-ponto-nigral degeneration [6].

On the other hand, the orexin system seems to be associated with clinical symptoms of patients with other mental disorders; in this sense, it was reported that patients with depression showed lower levels of orexin A in the cerebrospinal fluid, higher depression scores, and lowest levels of orexin A [105] (Table 4). It was described that the levels of orexin A are positively correlated with the BMI of the subjects, and that schizophrenic patients displayed significantly higher levels of orexin A, compared to controls [105] (Table 4). In Chinese patients with chronic schizophrenia, the BMIs were positively related with orexin 
A levels and negatively related with negative symptoms, suggesting that the level of orexin A might modify metabolic indexes (obese patients have a higher incidence of dyslipidemia) to increase the rates of overweight and obesity observed in these inpatients [105] (Table 4). The exact influence of antipsychotic drugs on orexin A levels and obesity remains to be established, although no relationship was found between BMI and different antipsychotic treatments [105].

\section{Relationships between Orexins and Other Substances}

Many substances (e.g., neuropeptides) are in a constant cross talk in the feeding brain pathways, including the hypothalamic nerve cell populations expressing orexin [108,109]. In this sense, it is known that nerve cells expressing orexin are inhibited by adenosine and GABA and are excited by acetylcholine, noradrenaline, thyrotropin-releasing hormone, glutamate and corticotropin-releasing factor [25]. In this section, the relationships between orexin and other substances (e.g., AgRP, ghrelin, leptin, NPY, opioids, GABA, and glutamate) are mentioned (Table 5, Figure 3).

Table 5. Orexins and other substances: relationships.

\begin{tabular}{|c|c|c|}
\hline Substance & Relationship & References \\
\hline \multirow{3}{*}{$\begin{array}{l}\text { Agouti-related } \\
\text { peptide }\end{array}$} & Lateral hypothalamus: agouti-related peptide activated neurons containing orexin & [110] \\
\hline & $\begin{array}{c}\text { Orexin A: stimulation of agouti-related peptide neurons of mediobasal hypothalamus. Effect blocked by neuropeptide } \mathrm{Y} \\
\text { receptor antagonists }\end{array}$ & [111] \\
\hline & Orexin: crucial for release of agouti-related peptide and maintenance of long-term energy balance & [112] \\
\hline \multirow{3}{*}{ Neuropeptide Y } & Orexin A: promotion of food consumption via the neuropeptide $Y$ pathway & [112] \\
\hline & Neurons containing orexin: projections from arcuate neurons expressing neuropeptide $Y$ & \multirow{2}{*}{ [113] } \\
\hline & Neuropeptide Y: regulation of food intake mechanisms mediated by orexins: & \\
\hline \multirow{8}{*}{ Opioids } & Diet-induced obesity: increased expressions of $\mu$-opioid receptors and orexin A in the basomedial amygdala & \multirow{2}{*}{ [114] } \\
\hline & Orexin A: augmented firing of basomedial amygdala gastric distension neurons and food consumption & \\
\hline & Ventral tegmental area: dynorphin inhibited reward behavior promoted by orexins & \multirow{3}{*}{ [115] } \\
\hline & Orexin A: increased hedonic intake. Expression of dynorphin and orexin receptors modified by obesity & \\
\hline & Paraventricular hypothalamic nucleus: $\mathrm{DYN}-\mathrm{A}_{1-13}$ increased hedonic intake, but not orexin & \\
\hline & $\begin{array}{c}\text { Paraventricular hypothalamic nucleus: action mediated by orexin A not regulated by opioids. Control of hedonic intake by } \\
\text { both peptides in an opposing manner }\end{array}$ & \multirow{2}{*}{ [116] } \\
\hline & $\begin{array}{l}\text { Orexin, opioid and non-opioid peptides: different roles in food intake/choice when non-palatable and palatable food } \\
\text { possibilities are available }\end{array}$ & \\
\hline & Orexin A: blocked satiety-inducing pro-opiomelanocortin neurons (orexin 1 receptor) & {$[117,118]$} \\
\hline \multirow{2}{*}{ Neurotensin } & Lateral hypothalamus: neurotensinergic neurons regulate body weight via orexin mechanisms & \multirow{2}{*}{ [119] } \\
\hline & Neurotensinergic neurons: needed to regulate the activity of the lateral hypothalamic neurons expressing orexin & \\
\hline \multirow{6}{*}{ Cannabinoids } & Orexin and cannabinoid receptors form heterodimers & \multirow{2}{*}{ [37] } \\
\hline & Orexin receptor activation: synthesis of 2-arachidonoyl glycerol & \\
\hline & Endocannabinoids: regulation of orexin expression controlling food intake & [120] \\
\hline & Central administration of RVD-hemopressin $(\alpha)$ : blocked food intake and decrease hypothalamic orexin A expression. & \multirow{2}{*}{ [121] } \\
\hline & RVD-hemopressin $(\alpha)$ : anorexigenic effect mediated by decrease in hypothalamic orexin A signaling & \\
\hline & $\begin{array}{l}\text { Arcuate nucleus (obese individuals): endocannabinoid/orexin A systems involved in the control of food intake and the } \\
\text { excitability of glucose-responsive neurons }\end{array}$ & [122] \\
\hline \multirow{3}{*}{ Ghrelin } & Central administration of ghrelin: activation of lateral hypothalamic orexigenic neurons & [123] \\
\hline & Animals without orexin: attenuated capacity of ghrelin to facilitate an operant performance for a diet rich in fat & [124] \\
\hline & $\begin{array}{c}\text { Ghrelin signaling in ventral hippocampus: downstream orexin receptor signaling in laterodorsal tegmental nucleus and } \\
\text { augmented meal size }\end{array}$ & [125] \\
\hline \multirow{3}{*}{ Leptin } & Peripheral orexin A: decreased leptin level & [20] \\
\hline & $\begin{array}{l}\text { Leptin: blockage of excitatory synaptic inputs to orexinergic lateral hypothalamic neurons projecting to the ventral } \\
\text { tegmental area }\end{array}$ & [126] \\
\hline & Administration of hedonically loaded food: blockage of inhibitory action of leptin on orexigenic lateral hypothalamic neurons & [127] \\
\hline \multirow{2}{*}{ GABA } & Muscimol: decreased hypothalamic prepro-orexin mRNA and blocked food consumption & \multirow{2}{*}{ [128] } \\
\hline & GABA: inhibition of orexinergic neurons of the lateral hypothalamus and decreased food intake & \\
\hline \multirow{3}{*}{ Glutamate } & Lateral hypothalamic orexin glucose-inhibited neurons: regulation of glutamate-mediated and control of reward-based feeding. & \multirow{3}{*}{ [129] } \\
\hline & Fasting: activation of lateral hypothalamic orexin glucose-inhibited neurons in low glucose. & \\
\hline & $\begin{array}{l}\text { Activation of lateral hypothalamic orexin glucose-inhibited neurons: in low glucose, increased glutamate signaling on } \\
\text { dopaminergic neurons in the ventral tegmental area and drive eat rewarding food; weight regain }\end{array}$ & \\
\hline
\end{tabular}




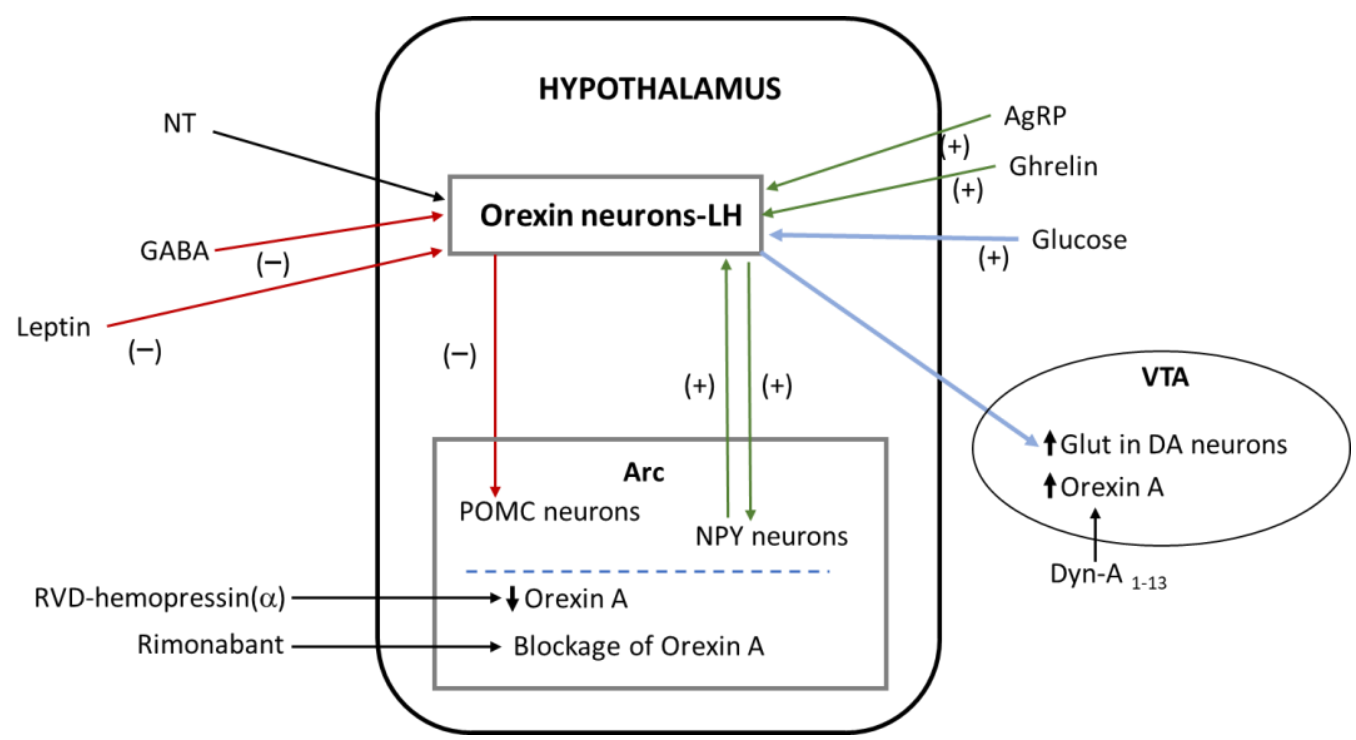

Figure 3. Interactions of orexin with other substances. Green arrows represent activation and red arrows represent inhibition. Blue arrows mean related actions: glucose activates the secretion of orexin by neurons of the lateral hypothalamus, and this activation leads to an increase in glutamate in dopaminergic neurons of the ventral tegmental area. Abbreviations: AgRP-agoutirelated protein; Arc — arcuate hypothalamic nucleus; DA—dopamine; Dyn-A—dynorphin-A; GABAgamma-aminobutyric acid; Glut-glutamate; LH—lateral hypothalamus; NPY—neuropeptide Y; NT—neurotensin; POMC—-pro-opiomelanocortin; VTA—ventral tegmental area.

\subsection{Agouti-Related Peptide (AgRP)}

Neurons containing orexin located in the lateral hypothalamus are activated after the administration of AgRP (which increases food intake), and it is known that orexin A stimulates AgRP neurons placed in the mediobasal hypothalamus; this finding suggests that orexin is crucial for the release of AgRP and the maintenance of long-term energy balance [110] (Table 5). Moreover, the effect mediated by orexin A is blocked by neuropeptide $Y$ receptor antagonists [111] (Table 5). The feeding mechanisms mediated by the three mentioned peptides must be studied in depth.

\subsection{Neuropeptide $Y$}

In the rat hypothalamic paraventricular nucleus, orexin A facilitates food intake and regulates the spontaneous firing of glucose-sensitive neurons [112]. Both effects were inhibited when the orexin 1 receptor antagonist SB-334,867 was administered and were weakened after treatment with a NPY 1 receptor antagonist (BMS-193,885) [112]. In addition, the administration of orexin $\mathrm{A}$ in the hypothalamic paraventricular nucleus induced the activation of the arcuate nucleus neurons expressing NPY [112]. This means that orexin A promotes food consumption via the NPY pathway (Table 5). Moreover, it is known that neurons containing orexin received projections from arcuate neurons expressing NPY and this means that food intake mechanisms mediated by orexins are regulated by NPY [113] (Table 5). As indicated above, the effects mediated by orexin A were blocked when a NPY receptor antagonist was administered [111].

\subsection{Opioids}

In obesity, opioids and orexin A located in the basomedial amygdala are involved in feeding behavior and in the control of gastric distension neuronal excitability [114]. In a diet-induced obesity rat model, the expressions of both $\mu$-opioid receptors and orexin A were increased in the basomedial amygdala [114] (Table 5). In the same experimental model, the administration of orexin $\mathrm{A}$ in the latter region augmented both the firing of basomedial amygdala gastric distension neurons and food consumption [114] (Table 5). 
Thus, these effects could be inhibited with orexin 1 receptor antagonists (e.g., SB-334,867) and could also be somewhat attenuated by the co-administration of naloxone [114].

It is known that dynorphin and orexin peptides are co-released; in the ventral tegmental area, dynorphin inhibits the reward behavior promoted by orexins; and in the paraventricular hypothalamic nucleus, dynorphin, but not orexin, increases hedonic intake [115] (Table 5). It is also known that obesity modifies the expression of both dynorphin and orexin receptors [115] (Table 5). The administration of DYN-A ${ }_{1-13}$ into the paraventricular hypothalamic nucleus increases hedonic intake as well as the injection of orexin A into the ventral tegmental area [115] (Table 5). In the paraventricular hypothalamic nucleus, orexin A blunted the increase (hedonic intake) mediated by DYN-A $1-13$; when an opioid receptor antagonist was administered in the same nucleus; a decrease in hedonic intake was observed but the administration of orexin A did not increase the hedonic intake. This means that in the paraventricular hypothalamic nucleus, the action mediated by orexin A is not regulated by opioids and that both peptides control the hedonic intake in an opposing manner (Table 5). It was reported that the administration of a non-opioid peptide (dynorphin $A_{2-17}$ ) in the paraventricular hypothalamic nucleus augmented the short-term food intake and energy expenditure [116]. The DYN-A $\mathrm{A}_{1-13}$ opioid peptide increased palatable food intake, whereas orexin-A and DYN-A $\mathrm{A}_{2-17}$ decreased this intake [116]. Moreover, orexin A increased chow intake [116]. The findings suggest that orexin, opioid and non-opioid peptides play different roles in food intake/choice when non-palatable and palatable food possibilities are available (Table 5). Finally, it was reported that orexin A, via the orexin 1 receptor, blocked satiety-inducing pro-opiomelanocortin neurons [117,118] (Table 5).

\subsection{Neurotensin}

Neurotensinergic neurons located in the lateral hypothalamus regulate body weight via orexin mechanisms [119] (Table 5). The activation of these neurons is also needed for regulating energy balance. A downregulation of orexin was observed when a complete loss of lateral hypothalamic neurons containing neurotensin was performed [119]. Thus, neurotensinergic neurons are needed to regulate the activity of the lateral hypothalamic neurons expressing orexin (Table 5).

\subsection{Cannabinoids}

It is known that orexin and cannabinoid receptors form heterodimers and that the activation of the orexin receptor promotes the synthesis of 2-arachidonoyl glycerol, an endocannabinoid [37] (Table 5). Thus, a functional interaction between both systems occurred. The peripheral administration of rimonabant (a cannabinoid 1 receptor antagonist) blocked the orexinergic action of orexin A when administered intracerebroventricularly; this means that endocannabinoids regulate the expression of orexin and, hence, control food intake [120] (Table 5).

RVD-hemopressin $(\alpha)$ is, respectively, a positive and negative allosteric modulator of the cannabinoid 2 and 1 receptors and it is known that the endocannabinoid system is involved in feeding behavior [121]. The central administration of RVD-hemopressin $(\alpha)$ blocked food intake and decreased the hypothalamic expression of orexin A [121] (Table 5). Thus, the anorexigenic effect mediated by RVD-hemopressin $(\alpha)$ is associated to a decrease in the hypothalamic orexin A signaling. The findings suggest that orexin A could be a new pharmacological strategy for targeting the endocannabinoid system (Table 5). In addition, it was reported that in obese animals, both endocannabinoid and orexin A systems regulate feeding behavior and arcuate glucose-responsive neurons [122]. The firing of these neurons was altered after the administration of AM-251 (a cannabinoid 1 receptor antagonist) or after the administration of orexin A [122]. The antagonist decreased feeding, whereas orexin A augmented food intake and, in addition, in the arcuate nucleus, both orexin and cannabinoid 1 receptor expressions of protein/mRNA were observed [122]. Thus, the results suggest that in the arcuate nucleus, both the endocannabinoid and orexin A systems 
are involved in the control of food intake and in the excitability of the glucose-responsive neurons in obese individuals (Table 5).

\subsection{Ghrelin}

Central administration of ghrelin activates the orexigenic neurons located in the lateral hypothalamus [123]; in animals lacking orexin, the appetite stimulatory action mediated by ghrelin is blocked [130]. It is known that the capacity of ghrelin to facilitate an operant performance for a diet rich in fat is attenuated in animals without orexin [124] (Table 5). The data suggest that the modulation of food reward and feeding by ghrelin is mediated by orexins located in lateral hypothalamic neurons. Another study showed that the central administration of ghrelin activates both non-orexinergic and orexinergic pathways involved in feeding regulation [131]. Thus, ghrelin is a potential anti-obesity therapeutic target due to the orexigenic properties of this hormone.

A new ventral hippocampus-lateral hypothalamus-laterodorsal tegmental nucleus pathway regulating meal size control was demonstrated [125]. Orexin neurons, located in the lateral hypothalamus, project to the hindbrain laterodorsal tegmental nucleus, and hence through this pathway, orexin and ghrelin interact [125]. Thus, ventral hippocampus ghrelin signaling augments meal size through a downstream orexin receptor signaling in the laterodorsal tegmental nucleus (Table 5).

\subsection{Leptin}

This adipocyte-derived substance decreases food intake, and it is known that orexin lateral hypothalamic neurons express leptin receptors [132]. Leptin decreases the increase in prepro-orexin during fasting and the expression of the hypothalamic orexin 1 receptor [66]. However, another study showed that the administration of leptin into the lateral hypothalamus increased the level of orexin mRNA [133]. The discrepancy could be due to the time in which the expression of orexin was studied or to the experimental animal model used [30]. In addition to the direct action of leptin on the lateral hypothalamic orexinergic neurons, indirect network mechanisms were also reported [134]. Thus, it is known that leptin, acting on neurotensinergic lateral hypothalamic neurons, inhibits orexinergic neurons by two GABA-independent mechanisms (opening of $\mathrm{K}_{\mathrm{ATP}}$ channels, and presynaptic inhibition of the excitatory neurotransmission) [134].

It is known that the peripheral orexin A decreases the level of leptin [20] (Table 5). Leptin regulates lateral hypothalamic neurons involved in the maintenance of energy homeostasis and in the regulation of food intake [126]. It was reported that leptin blocked the excitatory synaptic inputs to the lateral hypothalamic neurons expressing melaninconcentrating hormone or orexin that sends projections to the ventral tegmental area [126] (Table 5). Thus, it seems that leptin, by regulating the synaptic transmission, plays an important role in the maintenance of the energy homeostasis. This synaptic regulation is sensitive to energy states since both excessive energy storage (high-fat diet-induced obesity) and energy deficiency (acute fasting) attenuated leptin actions.

In lean and satiated mice that consumed a highly palatable food, an activation of the orexinergic neuros located in the lateral hypothalamus was observed; this activation was maintained even when the anorexigenic hormone leptin was administered [127]. In lean animals, it is also known that the overeating of palatable foods diminished when the galanin 2 receptor was activated in the lateral hypothalamus [127]. Thus, the inhibitory action on leptin on the lateral hypothalamic neurons containing orexin was blocked when a hedonically loaded food was administered, and during hedonic overeating, the blunted leptin sensitivity was reinstated when the galanin 2 receptor was activated (Table 5).

\subsection{GABA}

It is known that GABA neurons send projections to the lateral hypothalamus and that food intake increases the level of GABA in the same nucleus [128]. The administration of muscimol ( $\mathrm{GABA}_{\mathrm{A}}$ receptor agonist) decreases hypothalamic prepro-orexin mRNA 
and blocks food consumption [128] (Table 5). It was also reported that food consumption activated the GABAergic function in the lateral hypothalamus [128]. This activation, via $\mathrm{GABA}_{\mathrm{A}}$ receptors, terminates feeding, and it seems that GABA decreases food intake by inhibiting orexinergic neurons located in the lateral hypothalamus [128] (Table 5).

\subsection{Glutamate}

In the ventral tegmental area, it was reported that the lateral hypothalamic orexin glucose-inhibited neurons control reward-based feeding by regulating the transmission mediated by glutamate [129] (Table 5). Fasting augmented the activation of lateral hypothalamic orexin glucose-inhibited neurons in low glucose, whereas glucose blocked lateral hypothalamic neurons expressing orexin [129] (Table 5). In low glucose (after weight loss), an increased activation of lateral hypothalamic orexin glucose-inhibited neurons was observed; this was associated with increased glutamate signaling on ventral tegmental area dopaminergic neurons and eating rewarding food, leading to weight regain [129] (Table 5).

\section{Therapeutic Strategies}

Unfortunately, no effective pharmacological treatment for obesity was reported, and when these treatments were applied, important side effects were observed. It is also important to note that comorbidity between mood disorders and abnormal eating behaviors is frequent.

Orexin receptor antagonists are divided into DORAs (dual orexin1 and 2 receptor antagonists, e.g., suvorexant, and lemobrexant), SORA1s (selective orexin 1 receptor antagonists, e.g., SB-334,867) and SORA2s (selective orexin a receptor antagonists, e.g., seltorexant) [135]. Many studies used orexin receptor antagonists for the treatment of sleep disorders, depression, panic, anxiety, and drug addiction [135]. Concerning feeding disorders, it is known that orexin 1 receptor antagonists block hyperphagia [33] and that SB-334,867 (an orexin 1 receptor antagonist) inhibits meal size/feeding increase and the spontaneous firing of glucose-sensitive neurons mediated by orexin A [87,112]. Orexin receptors are a potential target for the development of anti-obesity drugs that antagonize the orexinergic system; in this sense, it was suggested that a pharmacotherapy targeting the orexin receptor 1 could selectively affect binge eating of palatable food while leaving basic appetite undiminished [7]. However, as mentioned above, the orexinergic system is involved in many physiological actions, making orexins an unspecific target against obesity since serious adverse effects can occur. Thus, due to the widespread distribution of neuropeptides in the central and peripheral nervous systems and the numerous physiological actions that these substances exert, therapeutic agents based on neuropeptides showed low efficacy; hence, drug development is complicate when targeting peptidergic systems (e.g., orexin). In addition, these systems are related with redundancy and for this reason, in general, the therapies applied are ineffective when they are directed against a single target. Thus, more preclinical/clinical studies must be performed to show clearly the beneficial effects mediated by the orexin receptor antagonists. For example, in feeding behavior, the effects of these antagonists must be studied in depth since it is known that each orexin receptor (1 and 2) plays a unique role in energy metabolism and, hence, each receptor exerts a differential function in obesity [89]. Accordingly, it seems that combination therapies are the best options for successful anti-obesity treatments. In these therapies, the physiological roles played by heterodimers or oligodimers of the orexin receptor must be fully investigated since, for example, heteromers (receptor-receptor interaction) are potential targets for food intake dysregulation. Hence a promising line of research is to understand in-depth these interactions as potential therapeutic targets in the hypothalamic nuclei, playing an important role in feeding behavior.

\section{Conclusions}

The orexinergic system is widely studied in mammals, birds, amphibians, reptiles and fish and the connectivity of this system is widely known. However, although some 
data are known, the signaling pathways activated by the orexinergic system must be fully demonstrated. Orexigenic peptides A and B originate from prepro-orexin, but the enzymes implicated in this mechanism are unknown. Orexinergic neurons are classified in different neurochemical subpopulations involved in the coordination and regulation of diverse physiological actions. These neurons project to different hypothalamic and extrahypothalamic regions, and thus, the complexity to fully understand the mechanisms involved in feeding behavior and motivation to consume food is increased, and a link between psychological problems and overweight is frequent.

The metabolic status controls the action of orexins on the intake of food. Diurnal variations in orexin levels were reported, and the expression of orexin varied during the development of obesity, indicating the differential roles played by orexin, at different feeding periods, in food consumption. There are contradictory data regarding the action of orexin A on the thyroid-pituitary axis; this must be solved by performing new experiments, as well as the sexually dimorphic role played by orexins. Moreover, the potentiation of the orexinergic system is a promising strategy for the improvement of cognitive/physiological actions in age-related disorders, although the concrete fluctuations of orexins observed in neurodegenerative diseases must be studied in depth. In addition, orexin A could be a new pharmacological strategy for targeting the endocannabinoid system.

The development of anti-obesity therapies must be focused on combination therapies, due to the widespread physiological actions exerted by the orexinergic system. For this reason, is crucial to understand in depth the relationships between orexins and other substances. It seems that the combination of different types of therapies is the best approach for the treatment of obesity and hence, this research line must be developed in the future.

Author Contributions: Both authors have contributed equally to the review. All authors have read and agreed to the published version of the manuscript.

Funding: This research received not external funding.

Institutional Review Board Statement: Not applicable.

Informed Consent Statement: Not applicable.

Data Availability Statement: Not applicable.

Acknowledgments: The authors gratefully acknowledge support from Programa XIII para Grupos GIR (Group BMD, Bases Moleculares del Desarrollo) of the University of Salamanca (Spain).

Conflicts of Interest: The authors declare no conflict of interest.

\section{References}

1. Liu, L.; Wang, Q.; Liu, A.; Lan, X.; Huang, Y.; Zhao, Z.; Jie, H.; Chen, J.; Zhao, Y. Physiological implications of orexins/hypocretins on energy metabolism and adipose tissue development. ACS Omega 2019, 5, 547-555. [CrossRef] [PubMed]

2. Milbank, E.; López, M. Orexins/hypocretins: Key regulators of energy homeostasis. Front. Endocrinol. 2019, 10, 830. [CrossRef]

3. Abdalla, M.M.I. Central and peripheral control of food intake. Endocr. Regul. 2017, 51, 52-70. [CrossRef]

4. Marcos, P.; Coveñas, R. Regulation of homeostasis by neuropeptide Y: Involvement in food intake. Curr. Med. Chem. 2022, in press.

5. Marcos, P.; Coveñas, R. Neuropeptidergic control of feeding: Focus on the galanin family of peptides. Int. J. Mol. Sci. 2021, 22, 2544. [CrossRef] [PubMed]

6. Sakurai, T.; Amemiya, A.; Ishii, M.; Matsuzaki, I.; Chemelli, R.M.; Tanaka, H.; Williams, S.C.; Richardson, J.A.; Kozlowski, G.P.; Wilson, S.; et al. Orexins and orexin receptors: A family of hypothalamic neuropeptides and G protein-coupled receptors that regulate feeding behavior. Cell 1998, 92, 573-585. [CrossRef]

7. Barson, J.R. Orexin/hypocretin and dysregulated eating: Promotion of foraging behavior. Brain Res. 2020, 1731, 145915. [CrossRef]

8. Barson, J.R.; Leibowitz, S.F. Orexin/Hypocretin system: Role in food and drug overconsumption. Int. Rev. Neurobiol. 2017, 136, 199-237. [CrossRef]

9. Muthmainah, M.; Gogos, A.; Sumithran, P.; Brown, R.M. Orexins (hypocretins): The intersection between homeostatic and hedonic feeding. J. Neurochem. 2021, 157, 1473-1494. [CrossRef]

10. Imperatore, R.; Palomba, L.; Cristino, L. Role of orexin-A in hypertension and obesity. Curr. Hypertens. Rep. 2017, 19, 34. [CrossRef]

11. Coccurello, R.; Maccarrone, M. Hedonic eating and the "Delicious Circle": From lipid-derived mediators to brain dopamine and back. Front. Neurosci. 2018, 12, 271. [CrossRef] [PubMed] 
12. Arrigoni, E.; Chee, M.J.S.; Fuller, P.M. To eat or to sleep: That is a lateral hypothalamic question. Neuropharmacology 2019, 154, 34-49. [CrossRef] [PubMed]

13. Michael, N.J.; Elmquist, J.K. Coordination of metabolism, arousal, and reward by orexin/hypocretin neurons. J. Clin. Invest. 2020, 130, 4540-4542. [CrossRef] [PubMed]

14. Ahmed, N.; Mattu, H.S.; Randeva, H.S. Orexins. In Handbook of Biologically Active Peptides, 2nd ed.; Kastin, A.B., Ed.; Academic Press: San Diego, CA, USA, 2013; pp. 1032-1037.

15. Azeez, I.A.; Igado, O.O.; Olopade, J.O. An overview of the orexinergic system in different animal species. Metab. Brain Dis. 2021, 36, 1419-1444. [CrossRef]

16. Wan, X.; Liu, Y.; Zhao, Y.; Sun, X.; Fan, D.; Guo, L. Orexin A affects HepG2 human hepatocellular carcinoma cells glucose metabolism via HIF-1 $\alpha$-dependent and -independent mechanism. PLoS ONE 2017, 12, e0184213. [CrossRef]

17. Gao, H.-R.; Zhuang, Q.-X.; Zhang, Y.-X.; Chen, Z.-P.; Li, B.; Zhang, X.-Y.; Zhong, Y.-T.; Wang, J.-J.; Zhu, J.-N. Orexin directly enhances the excitability of globus pallidus internus neurons in rat by co-activating OX1 and OX2 receptors. Neurosci. Bull. 2017, 33, 365-372. [CrossRef] [PubMed]

18. Kim, H.Y.; Hong, E.; Kim, J.I.; Lee, W. Solution structure of human orexin-A: Regulator of appetite and wakefulness. J. Biochem. Mol. Biol. 2004, 37, 565-573. [CrossRef]

19. Oesch, L.T.; Adamantidis, A.R. Sleep and metabolism: Implication of lateral hypothalamic neurons. Front. Neurol. Neurosci. 2021, 45, 75-90. [CrossRef]

20. Mediavilla, C. Bidirectional gut-brain communication: A role for orexin-A. Neurochem. Int. 2020, 141, 104882. [CrossRef] [PubMed]

21. Blais, A.; Drouin, G.; Chaumontet, C.; Voisin, T.; Couvelard, A.; Even, P.C.; Couvineau, A. Impact of orexin-A treatment on food intake, energy metabolism and body weight in mice. PLOS ONE 2017, 12, e0169908. [CrossRef]

22. Chen, X.-Y.; Chen, L.; Du, Y.-F. Orexin-A increases the firing activity of hippocampal CA1 neurons through orexin-1 receptors. J. Neurosci. Res. 2017, 95, 1415-1426. [CrossRef] [PubMed]

23. Clegg, D.J.; Air, E.L.; Woods, S.C.; Seeley, R.J. Eating elicited by orexin-A but not melanin-concentrating hormone, is opioid mediated. Endocrinology 2002, 143, 2995-3000. [CrossRef]

24. Durairaja, A.; Fendt, M. Orexin deficiency modulates cognitive flexibility in a sex-dependent manner. Genes Brain Behav. 2021, 20, e12707. [CrossRef] [PubMed]

25. Sagi, D.; de Lecea, L.; Appelbaum, L. Heterogeneity of hypocretin/orexin neurons. Front. Neurol. Neurosci. 2021, 45, 61-74. [CrossRef] [PubMed]

26. Mickelsen, L.E.; Kolling, F.W.; Chimileski, B.R.; Fujita, A.; Norris, C.; Chen, K.; Nelson, C.E.; Jackson, A.C. Neurochemical heterogeneity among lateral hypothalamic hypocretin/orexin and melanin-concentrating hormone neurons identified through single-cell gene expression analysis. eNeuro 2017, 4, 13-17. [CrossRef]

27. Yamanaka, A.; Kunii, K.; Nambu, T.; Tsujino, N.; Sakai, A.; Matsuzaki, I.; Miwa, Y.; Goto, K.; Sakurai, T. Orexin-induced food intake involves neuropeptide $Y$ pathway. Brain Res. 2000, 859, 404-409. [CrossRef]

28. Narita, M.; Nagumo, Y.; Hashimoto, S.; Narita, M.; Khotib, J.; Miyatake, M.; Sakurai, T.; Yanagisawa, M.; Nakamachi, T.; Shioda, S.; et al. Direct involvement of orexinergic systems in the activation of the mesolimbic dopamine pathway and related behaviors induced by morphine. J. Neurosci. 2006, 26, 398-405. [CrossRef]

29. de Lecea, L.; Sutcliffe, G. Hypocretins (orexins). In Handbook of Biologically Active Peptides, 2nd ed.; Kastin, A.B., Ed.; Academic Press: San Diego, CA, USA, 2013; pp. 812-818.

30. Davis, J.F.; Benoit, S.C. Orexins. In Handbook of Biologically Active Peptides, 2nd ed.; Kastin, A.B., Ed.; Academic Press: San Diego, CA, USA, 2013; pp. 1154-1159.

31. Thompson, M.D.; Sakurai, T.; Rainero, I.; Maj, M.C.; Kukkonen, J.P. Orexin receptor multimerization versus functional interactions: Neuropharmacological implications for opioid and cannabinoid signalling and pharmacogenetics. Pharmaceuticals 2017, 10, 79. [CrossRef]

32. Kilduff, T.S.; de Lecea, L. Mapping of the mRNAs for the hypocretin/orexin and melanin-concentrating hormone receptors: Networks of overlapping peptide systems. J. Comp. Neurol. 2001, 435, 1-5. [CrossRef]

33. Rodgers, R.J.; Halford, J.C.; Nunes de Souza, R.L.; Canto de Souza, A.L.; Piper, D.C.; Arch, J.R.; Upton, N.; Porter, R.A.; Johns, A.; Blundell, J.E. SB-334,867, a selective orexin-1 receptor antagonist, enhances behavioural satiety and blocks the hyperphagic effect of orexin-A in rats. Eur. J. Neurosci. 2001, 13, 1444-1452. [CrossRef]

34. Choi, D.L.; Davis, J.F.; Fitzgerald, M.E.; Benoit, S.C. The role of orexin-A in food motivation, reward-based feeling behavior and food-induced neuronal activation in rats. Neuroscience 2010, 167, 11-20. [CrossRef]

35. Funato, H.; Tsai, A.L.; Willie, J.T.; Kisanuki, Y.; Williams, C.; Sakurai, T.; Yanagisawa, M. Enhanced orexin receptor-2 signaling prevents diet-induced obesity and improves leptin sensitivity. Cell Metab. 2009, 9, 64-76. [CrossRef]

36. Randeva, H.S.; Karteris, E.; Grammatopoulos, D.; Hillhouse, E.W. Expression of orexin-A and functional orexin type 2 receptors in the human adult adrenals: Implications for adrenal function and energy homeostasis. J. Clin. Endocrinol. Metab. 2001, 86, 4808-4813. [CrossRef] [PubMed]

37. Berrendero, F.; Flores, A.; Robledo, R. When orexins meet cannabinoids: Bidirectional functional interactions. Biochem. Pharmacol. 2018, 157, 43-50. [CrossRef] [PubMed]

38. Holmqvist, T.; Johansson, L.; Östman, M.; Ammoun, S.; Akerman, K.; Kukkonen, J.P. OX1 orexin receptors couple to adenylyl cyclase regulation via multiple mechanisms. J. Biol. Chem. 2005, 280, 6570-6579. [CrossRef] 
39. Blanco, M.; López, M.; García-Caballero, T.; Gallego, R.; Vázquez-Boquete, A.; Morel, G.; Señarís, R.; Casanueva, F.; Diéguez, C. Cellular localization of orexin receptors in human pituitary. J. Clin. Endocrinol. Metab. 2001, 86, 3444-3447. [CrossRef] [PubMed]

40. Sánchez-García, A.; Cabral-Pacheco, G.A.; Zomosa-Signoret, V.C.; Ortiz-López, R.; Camacho, A.; Tabera-Tarello, P.M.; Garnica-López, J.A.; Vidaltamayo, R. Modular organization of a hypocretin gene minimal promoter. Mol. Med. Rep. 2018, 17, 2263-2270. [CrossRef]

41. Kelley, L.; Verlezza, S.; Long, H.; Loka, M.; Walker, C.D. Increased hypothalamic projections to the lateral hypothalamus and responses to leptin in rat neonates from high fat fed mothers. Front. Neurosci. 2020, 13, 1454. [CrossRef]

42. Blanco, A.M.; Bertucci, J.I.; Hatef, A.; Unniappan, S. Feeding and food availability modulate brain-derived neurotrophic factor, an orexigen with metabolic roles in zebrafish. Sci. Rep. 2020, 10, 10727. [CrossRef]

43. Harris, T.; Bugescu, R.; Kelly, J.; Makela, A.; Sotzen, M.; Sisk, C.; Atkin, G.; Pratt, R.; Crockett, E.; Leinninger, G. DLK1 expressed in mouse orexin neurons modulates anxio-depressive behavior but not energy balance. Brain Sci. 2020, 10, 975. [CrossRef]

44. Muschamp, J.W.; Domíguez, J.M.; Sato, S.M.; Shen, R.Y.; Hull, E.M. A role for hypocretin (orexin) in male sexual behavior. J. Neurosci. 2007, 27, 2837-2845. [CrossRef]

45. Alvarez, C.E.; Sutcliffe, J.G. Hypocretin is an early member of the incretin gene family. Neurosci. Lett. 2002, 324, 169-172. [CrossRef]

46. de Lecea, L.; Kilduff, T.S.; Peyron, C.; Gao, X.; Foye, P.E.; Danielson, P.E.; Fukuhara, C.; Battenberg, E.L.; Gautvik, V.T.; Bartlett, F.S.; et al. The hypocretins: Hypothalamus-specific peptides with neuroexcitatory activity. Proc. Natl. Acad. Sci. USA 1998, 95, 322-327. [CrossRef]

47. Chemelli, R.M.; Willie, J.T.; Sinton, C.M.; Elmquist, J.K.; Scammell, T.; Lee, C.; Richardson, J.A.; Williams, S.C.; Xiong, Y.; Kisanuki, Y.; et al. Narcolepsy in orexin knockout mice: Molecular genetics of sleep regulation. Cell 1999, 98, 437-451. [CrossRef]

48. Hernández, M.E.; Watkins, J.M.; Vu, J.; Hayward, L.F. DOCA/salt hypertension alters period1 and orexin-related gene expression in the medulla and hypothalamus of male rats: Diurnal influences. Auton. Neurosci. 2018, 210, 34-43. [CrossRef] [PubMed]

49. Silveyra, P.; Lux-Lantos, V.; Libertum, C. Both orexin receptors are expressed in rat ovaries and ovulation fluctuate with the estrous cycle: Effects of orexin receptor antagonists on gonadotropins and ovulation. Am. J. Physiol. Endocrinol. Metab. 2007, 293, E977-E985. [CrossRef] [PubMed]

50. Hellmann, J.; Drabek, M.; Yin, J.; Gunera, J.; Pröll, T.; Kraus, F.; Langmead, C.J.; Hübner, H.; Weikert, D.; Kolb, P.; et al. Structurebased development of a subtype-selective orexin 1 receptor antagonist. Proc. Natl. Acad. Sci. USA 2020, 117, 18059-18067. [CrossRef]

51. Palus-Chramiec, K.; Chrobok, L.; Kepczynski, M.; Lewandowski, M.H. Orexin A depolarises rat intergeniculate leaflet neurons through non-selective cation channels. Eur. J. Neurosci. 2019, 50, 2683-2693. [CrossRef] [PubMed]

52. Milasta, S.; Evans, N.A.; Ormiston, L.; Wilson, S.; Lefkowitz, R.J.; Milligan, G. The sustainability of interactions between the orexin-1 receptor and beta-arrestin-2 is defined by a single C-terminal cluster of hydroxy amino acids and modulates the kinetics of ERK MAPK regulation. Biochem. J. 2005, 387, 573-584. [CrossRef] [PubMed]

53. Jaeger, W.C.; Seeber, R.M.; Eidne, K.A.; Pfleger, K.D. Molecular determinants of orexin receptor-arrestin-ubiquitin complex formation. Br. J. Pharmacol. 2014, 171, 364-374. [CrossRef] [PubMed]

54. Duguay, D.; Belanger-Nelson, E.; Mongrain, V.; Beben, A.; Khatchadourian, A.; Cermakian, N. Dynein light chain Tctex-Type 1 modulates orexin signalling through its interaction with orexin 1 receptor. PLoS ONE 2011, 6, e26430. [CrossRef] [PubMed]

55. van den Pol, A.N.; Gao, X.B.; Obrietan, K.; Kilduff, T.S.; Belousov, A.B. Presynaptic and postsynaptic actions and modulation of neuroendocrine neurons by a new hypothalamic peptide, hypocretin/orexin. J. Neurosci. 1998, 18, 7962-7971. [CrossRef] [PubMed]

56. Digby, J.E.; Chen, J.; Tang, J.Y.; Lehnert, H.; Mattews, R.N.; Randeva, H.S. Orexin receptor expression in human adipose tissue: Effects of orexin-A and orexin-B. J. Endocrinol. 2006, 191, 129-136. [CrossRef]

57. Wortley, K.; Chang, G.; Davydova, Z.; Leibowitz, S. Orexin gene expression is increased during states of hypertrigliceridemia. Am. J. Physiol. Reg. Inter. Comp. Physiol. 2003, 284, R1454-R1465. [CrossRef]

58. Mondal, M.; Nakazato, M.; Date, Y.; Murakami, N.; Hanada, R.; Sakata, T.; Matsukura, S. Characterization of orexin-A and orexin-B in the microdissected rat brain nuclei and their contents in two obese rat models. Neurosci. Lett. 1999, 273, 45-48. [CrossRef]

59. Kirchgessner, A.L. Orexins in the brain-gut axis. Endocr. Rev. 2002, 23, 1-5. [CrossRef] [PubMed]

60. Tsuneki, H.; Wada, T.; Sasaoka, T. Role of orexin in the regulation of glucose homeostasis. Acta Physiol. 2010, 198, 335-348. [CrossRef]

61. Spinazzi, R.; Andreis, P.G.; Rossi, G.P.; Nussdorfer, G.G. Orexins in the regulation of the hipothalamic-pituitary-adrenal axis. Pharmacol. Rev. 2006, 58, 46-57. [CrossRef]

62. Wenzel, J.; Grabinski, N.; Knopp, C.A.; Dendorfer, A.; Ramanjaneya, M.; Randeva, H.S.; Ehrhart-Bornstein, M.; Dominiak, P.; Jöhren, O. Hypocretin/orexin increases the expression of steroidogenic enzymes in human adrenocortical NCI H295R cells. Am. J. Physiol. Regul. Integr. Comp. Physiol. 2009, 297, R1601-R1609. [CrossRef] [PubMed]

63. Tsuneki, H.; Anzawa, Y.; Soeda, Y.; Tokai, E.; Wada, T.; Kimura, M.; Yanagisawa, M.; Sakurai, T.; Sasaoka, T. Age-related insulin resistance in hypothalamus and peripheral tissues of orexin knockout mice. Diabetologia 2008, 51, 657-667. [CrossRef] [PubMed]

64. Cai, X.J.; Widdowson, P.S.; Harrold, J.; Wilson, S.; Buckingham, R.E.; Arch, J.R.; Tadayyon, M.; Clapham, J.C.; Wilding, J.; Williams, G. Hypothalamic orexin expression: Modulation by blood glucose and feeding. Diabetes 1999, 48, 2132-2137. [CrossRef] 
65. Teske, J.A.; Billington, C.J.; Kotz, C.M. Hyposecretin/orexin and energy expenditure. Acta Physiol. 2010, 198, 303-312. [CrossRef] [PubMed]

66. López, M.; Seoane, L.; García, M.C.; Lago, F.; Casanueva, F.F.; Señarís, R.; Diéguez, C. Leptin regulation of prepro-orexin and orexin receptor mRNA levels in the hypothalamus. Biochem. Biophys. Res. Commun. 2000, 269, 41-45. [CrossRef] [PubMed]

67. Namkoong, C.; Toshinai, K.; Zaved Waise, T.M.; Sakoda, H.; Sasaki, K.; Ueta, Y.; Kim, M.-S.; Minamino, N.; Nakazato, M. NERP-2 regulates gastric acid secretion and gastric emptying via the orexin pathway. Biochem. Biophys. Res. Commun. 2017, 485, 409-413. [CrossRef]

68. Greene, E.S.; Zampiga, M.; Sirri, F.; Ohkubo, T.; Dridi, S. Orexin system is expressed in avian liver and regulates hepatic lipogenesis via ERK1/2 activation. Sci. Rep. 2020, 10, 19191. [CrossRef]

69. Hara, J.; Beuckmann, C.T.; Nambu, T.; Willie, J.T.; Chemelli, R.M.; Sinton, C.M.; Sugiyama, F.; Yagami, K.; Goto, K.; Yanagisawa, M.; et al. Genetic ablation of orexin neurons in mice results in narcolepsy, hypophagia, and obesity. Neuron 2001, 30, 345-354. [CrossRef]

70. Willie, J.T.; Chemelli, R.M.; Sinton, C.M.; Yanagisawa, M. To eat or to sleep? Orexin in the regulation of feeding and wakefulness. Annu. Rev. Neurosci. 2001, 24, 429-458. [CrossRef] [PubMed]

71. Borgland, S.L.; Chang, S.J.; Bowers, M.S.; Tompson, J.L.; Vittoz, N.; Floresco, S.B.; Chou, J.; Chen, B.T.; Bonci, A. Orexin A/hypocretin-1 selectively promotes motivation for positive reinforcers. J. Neurosci. 2009, 29, 11215-11225. [CrossRef]

72. Zheng, H.; Patterson, L.M.; Berthoud, H.R. Orexin signaling in the vental tegmental area is required for high-fat appetite induced by opioid stimulation of the nucleus accumbens. J. Neurosci. 2007, 27, 11075-11082. [CrossRef] [PubMed]

73. Abounoori, M.; Maddah, M.M.; Akbari, E.; Houshmand, G.; Ardeshiri, M.R. The effect of orexin receptor antagonism on quinpirole-induced compulsive-like checking behavior in rats. Neurotox. Res. 2020, 38, 18-26. [CrossRef]

74. Fernández-García, J.M.; Carrillo, B.; Tezanos, P.; Collado, P.; Pinos, H. Genistein during development alters differentially the expression of POMC in male and female rats. Metabolites 2021, 11, 293. [CrossRef]

75. Freeman, L.R.; Bentzley, B.S.; James, M.H.; Aston-Jones, G. Sex differences in demand for highly palatable foods: Role of the orexin system. Int. J. Neuropsychopharmacol. 2021, 24, 54-63. [CrossRef] [PubMed]

76. Linehan, V.; Fang, L.Z.; Parsons, M.P.; Hirasawa, M. High-fat diet induces time-dependent synaptic plasticity of the lateral hypothalamus. Mol. Metab. 2020, 36, 100977. [CrossRef]

77. Li, S.; Kim, Y.; Chen, J.D.Z.; Madhoun, M.F. Intestinal electrical stimulation alters hypothalamic expression of oxytocin and orexin and ameliorates diet-induced obesity in rats. Obes. Surg. 2021, 31, 1664-1672. [CrossRef]

78. Lazzarino, G.P.; Acutain, M.F.; Canesini, G.; Andreoli, M.F.; Ramos, J.G. Cafeteria diet induces progressive changes in hypothalamic mechanisms involved in food intake control at different feeding periods in female rats. Mol. Cell Endocrinol. 2019, $498,110542$. [CrossRef]

79. Linehan, V.; Fang, L.Z.; Hirasawa, M. Short-term high-fat diet primes excitatory synapses for long-term depression in orexin neurons. J. Physiol. 2018, 596, 305-316. [CrossRef] [PubMed]

80. Tan, Y.; Hang, F.; Liu, Z.-W.; Stoiljkovic, M.; Wu, M.; Tu, Y.; Han, W.; Lee, A.M.; Kelley, C.; Hajós, M.; et al. Impaired hypocretin/orexin system alters responses to salient stimuli in obese male mice. J. Clin. Invest. 2020, 130, 4985-4998. [CrossRef]

81. Jin, T.; Jiang, Z.; Luan, X.; Qu, Z.; Guo, F.; Gao, S.; Xu, L.; Sun, X. Exogenous orexin-A microinjected into central nucleus of the amygdala modulates feeding and gastric motility in rats. Front. Neurosci. 2020, 14, 274. [CrossRef]

82. Meffre, J.; Sicre, M.; Diarra, M.; Marchessaux, F.; Paleressompoulle, D.; Ambroggi, F. Orexin in the posterior paraventricular thalamus mediates hunger-related signals in the nucleus accumbens core. Curr. Biol. 2019, 29, 3298-3306. [CrossRef] [PubMed]

83. Lai, F.; Cucca, F.; Frau, R.; Corrias, F.; Schlich, M.; Caboni, P.; Fadda, A.M.; Bassareo, V. Systemic administration of orexin a loaded liposomes potentiates nucleus accumbens shell dopamine release by sucrose feeding. Front. Psychiatry 2018, 9, 640. [CrossRef] [PubMed]

84. Franco-Pérez, J.; Manjarrez-Marmolejo, J.; Ballesteros-Zebadúa, P.; Neri-Santos, A.; Montes, S.; Suárez-Rivera, N.; Hernández-Cerón, M.; Pérez-Koldenkova, V. Chronic consumption of fructose induces behavioral alterations by increasing orexin and dopamine levels in the rat brain. Nutrients 2018, 10, 1722. [CrossRef]

85. Ramírez-Plascencia, O.D.; Saderi, N.; Escobar, C.; Salgado-Delgado, R.C. Feeding during the rest phase promotes circadian conflict in nuclei that control energy homeostasis and sleep-wake cycle in rats. Eur. J. Neurosci. 2017, 45, 1325-1332. [CrossRef]

86. Sun, J.; She, Y.; Fang, P.; Gu, X.; Zhang, Z. Time-restricted feeding prevents metabolic diseases through the regulation of galanin/GALR1 expression in the hypothalamus of mice. Eat Weight Disord. 2021. [CrossRef]

87. Williams, D.L.; Coiduras, I.I.; Parise, E.M.; Maske, C.B. Hindbrain orexin 1 receptors blunt intake suppression by gastrointestinal nutrients and cholecystokinin in male rats. Peptides 2020, 133, 170351. [CrossRef]

88. Yuan, W.; Wang, H.; Gong, Y. Prevention of cisplatin-induced nausea and vomiting by seabuckthorn (Hippophae rhamnoides L.) seed oil: Insights at the level of orexin-A in rats. Iran J. Basic Med. Sci. 2021, 24, 248-255. [CrossRef] [PubMed]

89. Kakizaki, M.; Tsuneoka, Y.; Takase, K.; Kim, S.J.; Choi, J.; Ikkyu, A.; Abe, M.; Sakimura, K.; Yanagisawa, M.; Funato, H. Differential roles of each orexin receptor signaling in obesity. iScience 2019, 20,1-13. [CrossRef]

90. Hagar, J.M.; Macht, V.A.; Wilson, S.P.; Fadel, J.R. Upregulation of orexin/hypocretin expression in aged rats: Effects on feeding latency and neurotransmission in the insular cortex. Neuroscience 2017, 350, 124-132. [CrossRef] [PubMed] 
91. Simão da Silva, E.; Flores, R.A.; Ribas, A.S.; Taschetto, A.P.; Faria, M.S.; Lima, L.B.; Metzger, M.; Donato, J., Jr.; Paschoalini, M.A. Injections of the of the $\alpha_{1}$-adrenoceptor antagonist prazosin into the median raphe nucleus increase food intake and fos expression in orexin neurons of free-feeding rats. Behav. Brain Res. 2017, 324, 87-95. [CrossRef] [PubMed]

92. Ghule, A.; Rácz, I.; Bilkei-Gorzo, A.; Leidmaa, E.; Sieburg, M.; Zimmer, A. Modulation of feeding behavior and metabolism by dynorphin. Sci. Rep. 2020, 10, 3821. [CrossRef] [PubMed]

93. Buonfiglio, D.; Parthimos, R.; Dantas, R.; Silva, R.C.; Gomes, G.; Andrade-Silva, J.; Ramos-Lobo, A.; Gaspar Amaral, F.; Matos, R.; Sinésio, J., Jr.; et al. Melatonin absence leads to long-term leptin resistance and overweight in rats. Front. Endocrinol. $2018,9,122$. [CrossRef]

94. Kaczmarek, P.; Skrzypski, M.; Pruszynska-Oszmalek, E.; Sassek, M.; Kolodziejski, P.A.; Billert, M.; Szczepankiewicz, D.; Wojciechowicz, T.; Maechler, P.; Nowak, K.W.; et al. Chronic orexin-A (hypocretin-1) treatment of type 2 diabetic rats improves glucose control and beta-cell functions. J. Physiol. Pharmacol. 2017, 68, 669-681. [PubMed]

95. Ueno, H.; Miyamoto, T.; Sanada, K.; Nakazono, K.; Tanaka, K.; Nishimura, H.; Nishimura, K.; Sonoda, S.; Yoshimura, M.; Maruyama, T.; et al. Changes in gene expressions of hypothalamic neuropeptides controlling feeding behaviors in bilateral nephrectomized rats. Neurosci. Lett. 2019, 711, 134426. [CrossRef]

96. Cristino, L.; Busetto, G.; Imperatore, R.; Ferrandino, I.; Palomba, L.; Silvestri, C.; Petrosino, S.; Orlando, P.; Bentivoglio, M.; Mackie, K.; et al. Obesity-driven synaptic remodeling affects endocannabinoid control of orexinergic neurons. Proc. Natl. Acad. Sci. USA 2013, 11, E2229-E2238. [CrossRef] [PubMed]

97. Cole, S.; Keefer, S.E.; Anderson, L.C.; Petrovich, G.D. Medial prefrontal cortex neural plasticity, orexin receptor 1 signaling, and connectivity with the lateral hypothalamus are Necessary in cue-potentiated feeding. J. Neurosci. 2020, 40, 1744-1755. [CrossRef]

98. Gazea, M.; Patchev, A.V.; Anderzhanova, E.; Leidmaa, E.; Pissioti, A.; Flachskamm, C.; Almeida, O.F.X.; Kimura, M. Restoring serotonergic homeostasis in the lateral hypothalamus rescues sleep disturbances induced by early-life obesity. J. Neurosci. 2018, 38, 441-451. [CrossRef] [PubMed]

99. González, J.A.; Jensen, L.T.; Iordanidou, P.; Strom, M.; Fugger, L.; Burdakov, D. Inhibitory interplay between orexin neurons and eating. Curr. Biol. 2016, 26, 2486-2491. [CrossRef] [PubMed]

100. True, C.; Arik, A.; Lindsley, S.; Kirigiti, M.; Sullivan, E.; Kievit, P. Early high-fat diet exposure causes dysregulation of the orexin and dopamine neuronal populations in nonhuman primates. Front. Endocrinol. 2018, 9, 508. [CrossRef]

101. Michels, N. Biological underpinnings from psychosocial stress towards appetite and obesity during youth: Research implications towards metagenomics, epigenomics and metabolomics. Nutr. Res. Rev. 2019, 32, 282-293. [CrossRef] [PubMed]

102. Salomon, R.M.; Ripley, B.; Kennedy, J.S.; Johnson, B.; Schmidt, D.; Zeitzer, J.M.; Nishino, S.; Mignot, E. Diurnal variation of cerebrospinal fluid hypocretin-1 (orexin-A) levels in control and depressed subjects. Biol. Psychiatry 2003, 54, 96-104. [CrossRef]

103. Mäkelä, K.A.; Karhu, T.; Jurado Acosta, A.; Vakkuri, O.; Leppäluoto, J.; Herzig, K.-H. Plasma orexin-A levels do not undergo circadian rhythm in young healthy male subjects. Front. Endocrinol. 2018, 9, 710. [CrossRef] [PubMed]

104. Adam, J.; Menheere, P.; van Dielen, F.; Soeters, P.; Buutman, W.; Grave, J. Decreased plasma orexin-A levels in obese individuals. Int. J. Obs. 2002, 26, 274-276. [CrossRef] [PubMed]

105. Liu, Z.; Zhang, Y.; Zhao, T.; Wang, J.; Xia, L.; Zhong, Y.; Yang, Y.; Ning, X.; Zhang, Y.; Ren, Z.; et al. A higher body mass index in Chinese inpatients with chronic schizophrenia is associated with elevated plasma orexin-A levels and fewer negative symptoms. Nord. J. Psychiatry 2020, 74, 525-532. [CrossRef] [PubMed]

106. Köroğlu, Ç.; Gluck, M.E.; Traurig, M.; Votruba, S.B.; Krakoff, J.; Stinson, E.J.; Chen, P.; Bogardus, C.; Piaggi, P.; Baier, L.J. Assessing established BMI variants for a role in nighttime eating behavior in robustly phenotyped Southwestern American Indians. Eur. J. Clin. Nutr. 2020, 74, 1718-1724. [CrossRef] [PubMed]

107. Fronczek, R.; van Geest, S.; Frolich, M.; Overeem, S.; Roelandse, F.W.C.; Lammers, G.J.; Swaab, D.F. Hypocretin (orexin) loss in Alzheimer's disease. Neurobiol. Aging 2012, 33, 1642-1650. [CrossRef]

108. Klockars, A.; Levine, A.S.; Olszewski, P.K. Hypothalamic integration of the endocrine signaling related to food intake. Curr. Top. Behav. Neurosci. 2019, 43, 239-269. [CrossRef] [PubMed]

109. Goforth, P.B.; Myers, M.G. Roles for orexin/hypocretin in the control of energy balance and metabolism. Curr. Top. Behav. Neurosci. 2017, 33, 137-156. [CrossRef] [PubMed]

110. van den Top, M.; Lee, K.; Whyment, A.; Blanks, A.; Spanswick, D. Orexin-sensitive NPY/AgRP pacemaker neurons in the hypothalamic arcuate nucleus. Nat. Neurosci. 2004, 7, 493-494. [CrossRef]

111. Ida, T.; Nakahara, K.; Kuroiwa, T.; Fukui, K.; Nakazato, M.; Murakami, T.; Murakami, N. Both corticotropin releasing factor and neuropeptide $\mathrm{Y}$ are involved in the effect of orexin (hypocretin) on the food intake in rats. Neurosci. Lett. 2000, 293, 119-122. [CrossRef]

112. Wang, C.; Han, X.; Guo, F.; Sun, X.; Luan, X.; Luo, X. Orexin-A signaling in the paraventricular nucleus modulates spontaneous firing of glucose-sensitive neurons and promotes food intake via the NPY pathway in rats. Biochem. Biophys. Res. Commun. 2018, 505, 162-167. [CrossRef]

113. Horvath, T.L. The hardship of obesity: A soft-wired hypothalamus. Nat. Neurosci. 2005, 8, 561-565. [CrossRef]

114. Wang, M.; Sun, X.; Guo, F.; Luan, X.; Wang, C.; Xu, L. Activation of orexin-1 receptors in the amygdala enhances feeding in the diet-induced obesity rats: Blockade with $\mu$-opioid antagonist. Biochem. Biophys. Res. Commun. 2018, 503, 3186-3191. [CrossRef] 
115. Mattar, P.; Uribe-Cerda, S.; Pezoa, C.; Guarnieri, T.; Kotz, C.M.; Teske, J.A.; Morselli, E.; Perez-Leighton, C. Brain site-specific regulation of hedonic intake by orexin and DYN peptides: Role of the PVN and obesity. Nutr. Neurosci. 2020, 1-10. [CrossRef] [PubMed]

116. Alvarez, B.; Barrientos, T.; Gac, L.; Teske, J.A.; Perez-Leighton, C.E. Effects on hedonic feeding, energy expenditure and balance of the non-opioid peptide DYN-A 2-17. Neuroscience 2018, 371, 337-345. [CrossRef]

117. Morello, G.; Imperatore, R.; Palomba, L.; Finelli, C.; Labruna, G.; Pasanisi, F.; Sacchetti, L.; Buono, L.; Piscitelli, F.; Orlando, P.; et al. Orexin-A represses satiety-inducing POMC neurons and contributes to obesity via stimulation of endocannabinoid signaling. Proc. Natl. Acad. Sci. USA 2016, 113, 4759-4764. [CrossRef] [PubMed]

118. Williams, D.L. Neural integration of satiation and food reward: Role of GLP-1 and orexin pathways. Physiol. Behav. 2014, 136, 194-199. [CrossRef]

119. Brown, J.; Sagante, A.; Mayer, T.; Wright, A.; Bugescu, R.; Fuller, P.M.; Leinninger, G. Lateral hypothalamic area neurotensin neurons are required for control of orexin neurons and energy balance. Endocrinology 2018, 159, 3158-3176. [CrossRef]

120. Crespo, I.; Gómez de Heras, R.; Rodríguez de Fonseca, F.; Navarro, M. Pretreatment with subeffective doses of Rimonabant attenuates orexigenic actions of orexin A-hypocretin 1. Neuropharmacology 2008, 54, 219-225. [CrossRef] [PubMed]

121. Recinella, L.; Chiavaroli, A.; Ferrante, C.; Mollica, A.; Macedonio, G.; Stefanucci, A.; Dimmito, M.P.; Dvorácskó, S.; Tömböly, C.; Brunetti, L.; et al. Effects of central RVD-hemopressin $(\alpha)$ administration on anxiety, feeding behavior and hypothalamic neuromodulators in the rat. Pharmacol. Rep. 2018, 70, 650-657. [CrossRef] [PubMed]

122. Yang, D.; Xu, L.; Guo, F.; Sun, X.; Zhang, D.; Wang, M. Orexin-A and endocannabinoid signaling regulate glucose-responsive arcuate nucleus neurons and feeding behavior in obese rats. Neuropeptides 2018, 69, 26-38. [CrossRef]

123. Lawrence, C.B.; Snape, A.C.; Baudoin, F.M.-H.; Luckman, S.M. Acute central ghrelin and GH secretagogues induce feeding and activate brain appetite. Endocrinology 2003, 143, 155-162. [CrossRef]

124. Perello, M.; Sakata, I.; Birnbaum, S.; Chuang, J.-C.; Osborne-Lawrence, S.; Rovinsky, S.A.; Woloszyn, J.; Yanagisawa, M.; Lutter, M.; Zigman, J.M. Ghrelin increases the rewarding value of high-fat diet in an orexin-dependent manner. Biol. Psychiatry 2010, 67, 880-886. [CrossRef]

125. Suárez, A.N.; Liu, C.M.; Cortella, A.M.; Noble, E.E.; Kanoski, S.E. Ghrelin and orexin interact to increase meal size through a descending hippocampus to hindbrain signaling pathway. Biol. Psychiatry 2020, 87, 1001-1011. [CrossRef]

126. Liu, J.-J.; Bello, N.T.; Pang, Z.P. Presynaptic regulation of leptin in a defined lateral hypothalamus-ventral tegmental area neurocircuitry depends on energy state. J. Neurosci. 2017, 37, 11854-11866. [CrossRef] [PubMed]

127. Leidmaa, E.; Gazea, M.; Patchev, A.V.; Pissioti, A.; Gassen, N.C.; Kimura, M.; Liposits, Z.; Kallo, I.; Almeida, O.F.X. Blunted leptin sensitivity during hedonic overeating can be reinstated by activating galanin 2 receptors (Gal2R) in the lateral hypothalamus. Acta Physiol. 2020, 228, e13345. [CrossRef] [PubMed]

128. Yonemochi, N.; Ardianto, C.; Ueda, D.; Kamei, J.; Ikeda, H. GABAergic function in the lateral hypothalamus regulates feeding behavior: Possible mediation via orexin. Neuropsychopharmacol. Rep. 2019, 39, 289-296. [CrossRef]

129. Teegala, S.B.; Sheng, Z.; Dalal, M.S.; Hirschberg, P.R.; Beck, K.D.; Routh, V.H. Lateral hypothalamic orexin glucose-inhibited neurons may regulate reward-based feeding by modulating glutamate transmission in the ventral tegmental area. Brain Res. 2020, 1731, 145808. [CrossRef]

130. Toshinai, K.; Date, Y.; Murakami, N.; Shimada, M.; Mondal, M.S.; Shimbara, T.; Guan, J.L.; Wang, Q.P.; Funahashi, H.; Sakurai, T.; et al. Ghrelin-induced food intake is mediated via the orexin pathway. Endocrinology 2003, 144, 1506-1512. [CrossRef]

131. So, M.; Hashimoto, H.; Saito, R.; Yamamoto, Y.; Motojima, Y.; Ueno, H.; Sonoda, S.; Yoshimura, M.; Maruyama, T.; Kusuhara, K.; et al. Inhibition of ghrelin-induced feeding in rats by pretreatment with a novel dual orexin receptor antagonist. $J$. Physiol. Sci. 2018, 68, 129-136. [CrossRef]

132. Håkansson, M.; de Lecea, L.; Sutcliffe, J.G.; Yanagisawa, M.; Meister, B. Leptin receptor-and STAT3-immunoreactivities in hypocretin/orexin neurones of the lateral hypothalamus. J. Neuroendocrinol. 1999, 11, 653-663. [CrossRef]

133. Louis, G.W.; Leinninger, G.M.; Rhodes, C.J.; Myers, M.G. Direct innervation and modulation of orexin neurons by lateral hypothalamic LepRb neurons. J. Neurosci. 2010, 30, 11278-11287. [CrossRef] [PubMed]

134. Goforth, P.B.; Leinninger, G.M.; Patterson, C.M.; Satin, L.S.; Myers, M.G. Leptin acts via lateral hypothalamic area neurotensin neurons to inhibit orexin neurons by multiple GABA-independent mechanisms. J. Neurosci. 2014, 34, 11405-11415. [CrossRef] [PubMed]

135. Han, Y.; Yuan, K.; Zheng, Y.; Lu, L. Orexin receptor antagonists as emerging treatments for psychiatric disorders. Neurosci. Bull. 2020, 36, 432-448. [CrossRef] [PubMed] 